\title{
Vegetation Communities at Big Muddy National Fish and Wildlife Refuge, Missouri
}

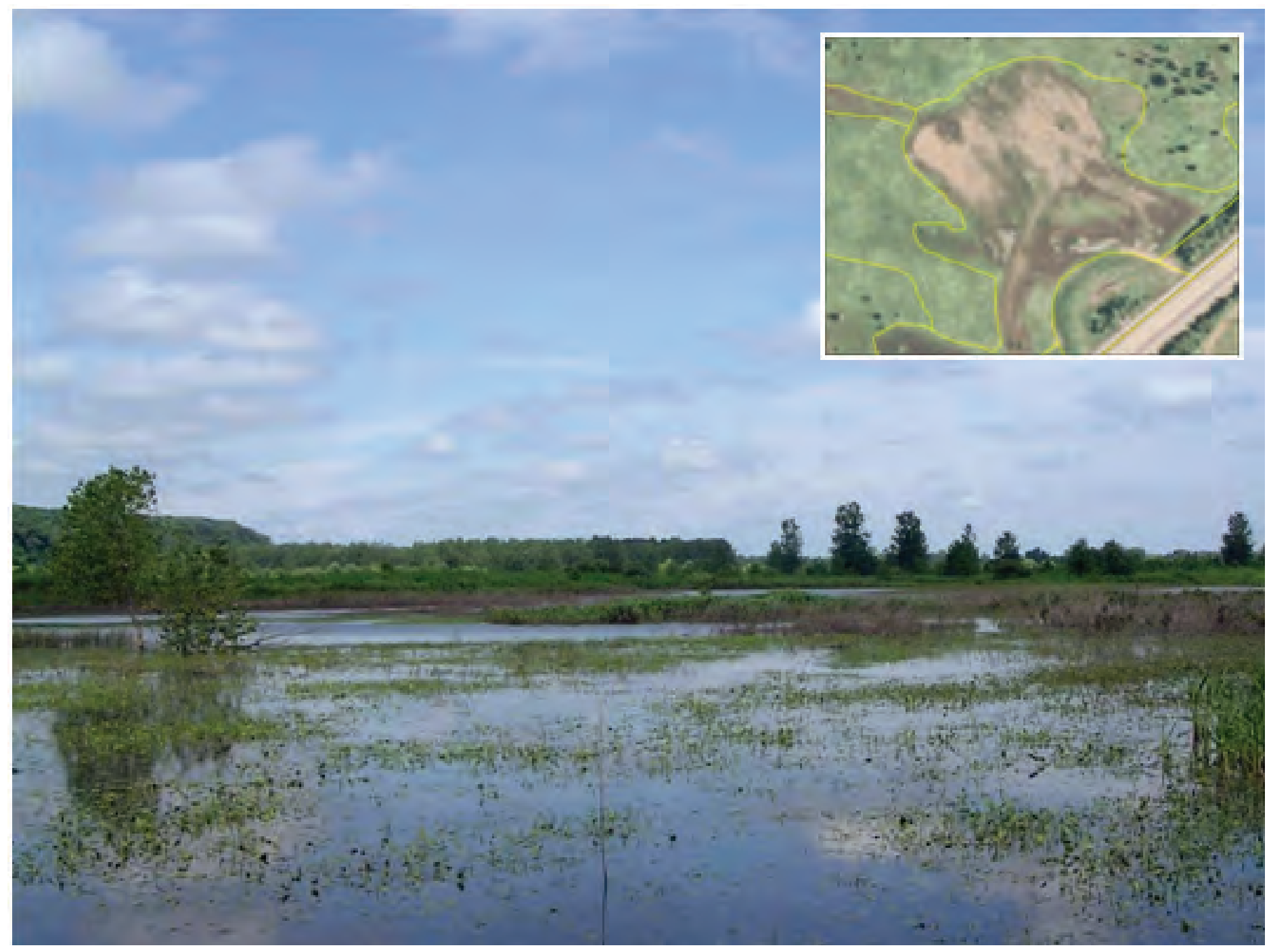

Open-File Report 2011-1038 
Cover: Wetland area classified as the National Vegetation Classification System Midwest Ephemeral Pond (CEGL002430), and the same area as mapped from 2007 U.S. Department of Agriculture National Agricultural Imagery Program aerial photographs (inset). 


\section{Vegetation Communities at Big Muddy National Fish and Wildlife Refuge, Missouri}

By Matthew A. Struckhoff, Keith W. Grabner, and Esther D. Stroh

Open-File Report 2011-1038 


\section{U.S. Department of the Interior \\ KEN SALAZAR, Secretary \\ U.S. Geological Survey \\ Marcia K. McNutt, Director}

\section{U.S. Geological Survey, Reston, Virginia: 2011}

For more information on the USGS - the Federal source for science about the Earth, its natural and living resources, natural hazards, and the environment, visit http://www.usgs.gov or call 1-888-ASK-USGS

For an overview of USGS information products, including maps, imagery, and publications, visit http://www.usgs.gov/pubprod

Any use of trade, product, or firm names is for descriptive purposes only and does not imply endorsement by the U.S. Government.

Although this report is in the public domain, permission must be secured from the individual copyright owners to reproduce any copyrighted materials contained within this report.

Suggested citation:

Struckhoff, M.A., Grabner, K.W., and Stroh E.D, 2011, Vegetation communities at Big Muddy National Fish and Wildlife Refuge, Missouri: U.S. Geological Survey Open-File Report 2011-1038, 29 p. with Appendix. 


\section{Contents}

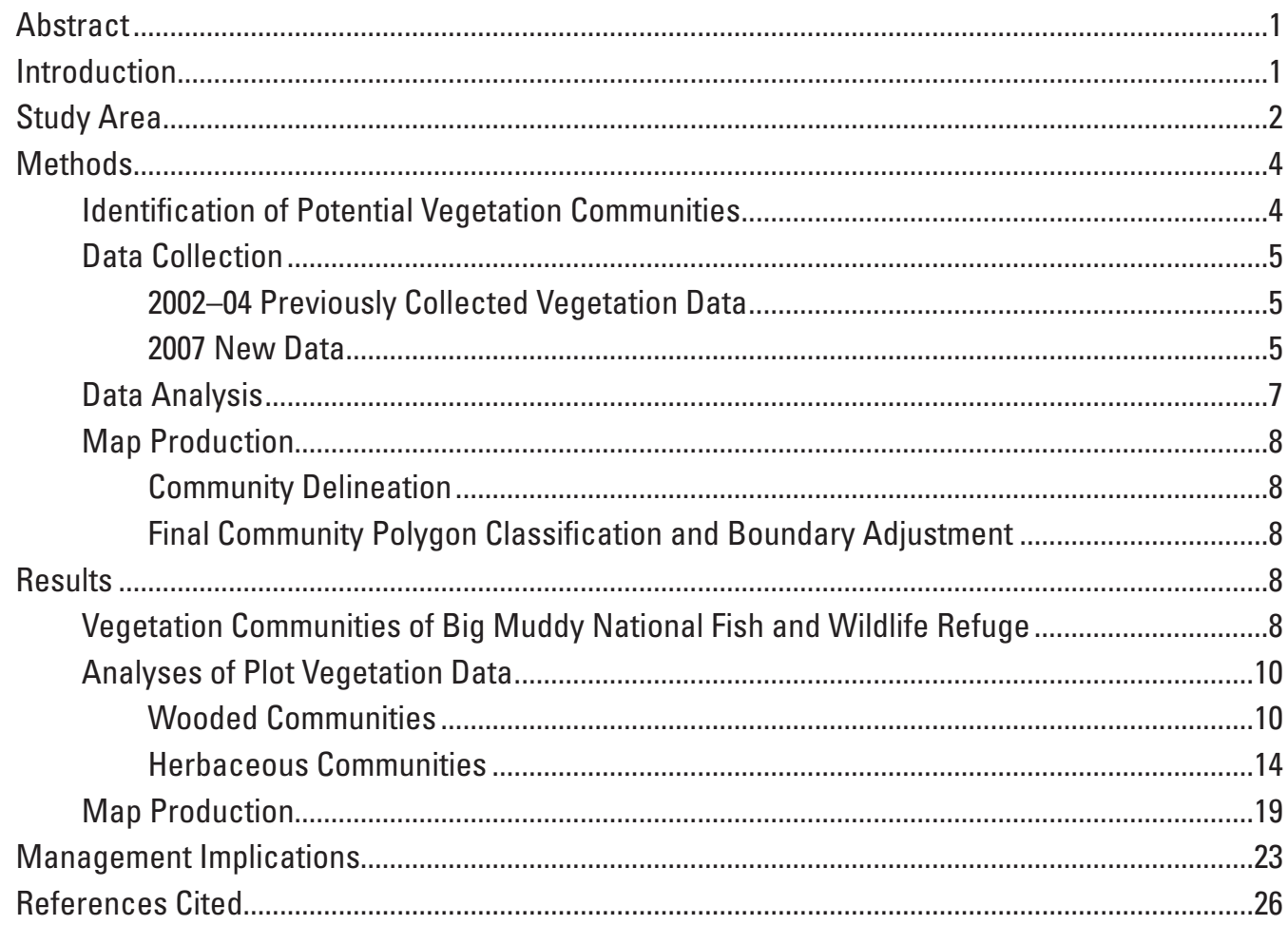

\section{Figures}

1. Map showing Big Muddy National Fish and Wildlife Refuge management units,

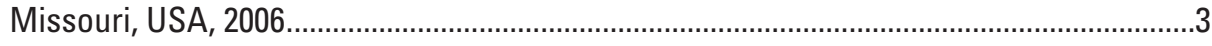

2. Diagram showing monumentation used to permanently mark plots ..................................6

3. Diagram showing Beyond North American Weed Management Association (NAWMA) plot design used during 2007 sampling ...........................................................6

4. Graph showing non-metric Multidimensional Scaling output for woody communities based on woody stem basal area

5. Graph showing non-metric Multidimensional Scaling output for woody communities based onwoody stem density.

6. Graph showing non-metric Multidimensional Scaling output for herbaceous communities with vectors indicating direction of increase for those species most correlated with the data structure

7. Map showing vegetation for portion of floodplain at Overton Bottoms unit at Big Muddy National Fish and Wildlife Refuge, Missouri

8. Map showing vegetation for upland section of Saint Aubert Island unit at Big Muddy National Fish and Wildlife Refuge, Missouri.. 


\section{Tables}

1. Existing and potential National Vegetation Classification System (NVCS)

Associations at Big Muddy National Fish and Wildlife Refuge

. .9

2. Existing ruderal vegetation associations and other mapped features at Big Muddy National Fish and Wildlife Refuge

3. Woody species measures for woody dominated vegetation associations as classified based on field data and observations...

4. Multiple-Response Permutation Procedure results for woody communities based on woody stem basal area

5. Multiple-Response Permutation Procedure results for woody communities based on woody stem density

6. Results of Multiple Response Permutation Procedure analysis of herbaceous communities

7. Polygon count and area for mapped communities at Big Muddy National Fish and Wildlife Refuge 


\section{Conversion Factors}

\begin{tabular}{|c|c|c|}
\hline Multiply & By & To obtain \\
\hline \multicolumn{3}{|c|}{ Length } \\
\hline inch (in) & 2.54 & centimeter $(\mathrm{cm})$ \\
\hline foot $(\mathrm{ft})$ & 0.3048 & meter $(\mathrm{m})$ \\
\hline mile (mi) & 1.609 & kilometer $(\mathrm{km})$ \\
\hline \multicolumn{3}{|c|}{ Area } \\
\hline acre & 4,047 & square meter $\left(\mathrm{m}^{2}\right)$ \\
\hline acre & 0.4047 & hectare (ha) \\
\hline acre & 0.004047 & square kilometer $\left(\mathrm{km}^{2}\right)$ \\
\hline square foot $\left(\mathrm{ft}^{2}\right)$ & 0.09290 & square meter $\left(\mathrm{m}^{2}\right)$ \\
\hline square mile $\left(\mathrm{mi}^{2}\right)$ & 259.0 & hectare (ha) \\
\hline square mile $\left(\mathrm{mi}^{2}\right)$ & 2.590 & square kilometer $\left(\mathrm{km}^{2}\right)$ \\
\hline
\end{tabular}

\section{SI to Inch/Pound}

\begin{tabular}{lcl}
\hline \multicolumn{1}{c}{ Multiply } & By & \multicolumn{1}{c}{ To obtain } \\
\hline cemtimeter $(\mathrm{cm})$ & Length & \\
meter $(\mathrm{m})$ & 0.39 & inch (in) \\
kilometer $(\mathrm{km})$ & 3.281 & foot (ft) \\
meter $(\mathrm{m})$ & 0.6214 & mile (mi) \\
\hline & 1.094 & yard (yd) \\
\hline square meter $\left(\mathrm{m}^{2}\right)$ & Area & acre \\
hectare (ha) & 0.0002471 & acre \\
square kilometer $\left(\mathrm{km}^{2}\right)$ & 2.471 & acre \\
hectare (ha) & 247.1 & square mile $\left(\mathrm{mi}^{2}\right)$ \\
\hline
\end{tabular}

Horizontal coordinate information is referenced to the North American Datum of 1983 (NAD 83). 



\title{
Vegetation Communities at Big Muddy National Fish and Wildlife Refuge, Missouri
}

\author{
By Matthew A. Struckhoff, Keith W. Grabner, Esther D. Stroh
}

\section{Abstract}

New and existing data were used to describe and map vegetation communities at Big Muddy National Fish and Wildlife Refuge. Existing data had been gathered during the growing seasons of 2002, 2003, and 2004. New data were collected in 2007 to describe previously unsampled communities and communities within which insufficient data had been collected. Plot data and field observations were used to describe 17 natural and semi-natural communities at the Association level of the National Vegetation Classification System (NVCS). Four ruderal communities not included in the NVCS are also described. Data were used to inform delineation of communities using aerial photos from 2000, 2002, 2003, 2005, 2006, and 2007. During this process, eleven additional land cover classes including cultural features, managed vegetation communities, and water features were identified. These features were mapped, some were described, but no vegetation data were collected. In 2009, nearly all community polygons were field visited and classified to the Association level. When necessary, polygon boundaries were adjusted based on field observations. The final map includes 482 polygons of 27 land cover classes encompassing 3,174 hectares on 5 units of the refuge. Data and information will inform the development of the refuge Comprehensive Conservation Plan.

\section{Introduction}

Historically, the lower portion of the Missouri River, from Sioux City, Iowa to Saint Louis, Missouri, consisted of braided and shifting channels, numerous snags, islands, sandbars, oxbow lakes, and ephemeral wetlands (Galat and others, 1998; Funk and Robinson, 1974; Weaver, 1960). Before channel management and engineering, the Missouri River flood plain supported a diverse suite of forested communities, shrublands, prairies, swamps, and marshes (Nigh and Schroeder, 2002). Flooding cycles included an early spring flood (because of upstream snowmelt), followed by an early summer flood (because of continued upstream snowmelt and rainfall), and by a gradually diminished river flow during the summer and into the fall and winter (Galat and others, 1998). This flooding cycle, as in most riparian systems, helped to produce a mosaic of vegetation and wetland communities (Gurnell, 1997).

The Missouri River historically has been used as a transportation corridor, but the constantly shifting channel, dynamic sandbars, and the presence of partially buried and floating logs made river navigation treacherous. From 1832 to 1900 the first attempt at managing the river for transportation was attempted; large woody debris was removed from the channel to improve navigation (Funk and Robinson, 1974). From 1884 to 1902, management of the Missouri River was the responsibility of the Missouri River Commission, with the objective of improving the navigation of the river through uniformly contracting the width of the river, fixing its location and protecting all banks from erosion (Suter, 1887, in Funk and Robinson, 1974). In 1912, the U.S. Army Corps of Engineers (USACE) began construction of a levee system, and by 1933 the river channel was being improved for navigation (Funk and Robinson, 1974). Recent river management includes the construction of wing dikes and revetments to stabilize the river bank and to create a narrowed, self-dredging navigation channel (Jacobson, 2006). The results of river management have been a loss of wetlands and riparian forest habitat but an increase in agriculture along the Missouri River corridor (Galat and others, 1998).

In 1993, 1995 and 1996, the Lower Missouri River flooded, inundating nearly the entire flood plain from Kansas City to Saint Louis, Missouri (Galat and others, 1998). These multiple, record-setting floods stimulated a reevaluation of river management (Galat and others, 1998). State and federal programs were established to purchase or protect lands within the Missouri River flood plain. In 1993 and 1994, Congress authorized and provided funding for the U.S. Fish and Wildlife Service (USFWS) to establish the Big Muddy National Fish and Wildlife Refuge (BMNFWR) on more than 6,400 hectares (ha; 16,000 acres [ac]) between Kansas City and Saint Louis, Missouri (U.S. Fish and Wildlife Service, 1999). The BMNFWR began acquiring land in 1995 and currently manages approximately 4,500 ha (11,000 ac); most are lands made unsuitable for agriculture by scouring and sand deposition during the floods of 1993 and 1995. More recently, the refuge has been authorized to expand to 24,280 ha $(60,000 \mathrm{ac})$ and has begun negotiations to acquire lands to meet that target. The goals for the BMNFWR, as outlined in the environmental 
impact statement prepared for this proposed expansion (U.S. Fish and Wildlife Service, 1999), are:

- Restore natural flood-plain conditions and associated native habitats including bottomland forest, wetlands, wet prairie, and other grasslands.

- Restore natural riverine functions on public lands by connecting the river with the flood plain, allowing some natural meandering, widening the channel, and creating sandbars, chutes, sloughs, and other aquatic features.

- Restore habitat sufficient to protect federally-listed threatened and endangered species and candidate species within the project area.

- Conserve, manage, and restore biodiversity and abundance of native endemic fish and wildlife populations.

- Provide additional public areas for compatible fish and wildlife-oriented recreation, and increase public understanding of Missouri River resources.

To meet the goals outlined in the Interim Comprehensive Management Plan, BMNFWR staff must know the current condition of vegetation, plant communities, and wildlife habitat within the refuge. Vegetation data had been collected in 2002, 2003 and 2004 in association with 400 bird survey points in 3 coarse vegetation types (early successional forest, mature forests, and wet prairies). These data had not been subsequently analyzed. In 2006, as part of the USGS Science Support Partnership (SSP) Program, a study was initiated to describe and map vegetation on the five units of Big Muddy National Fish and Wildlife Refuge for which these data had been collected. In 2007, additional funds provided for the establishment and sampling of permanent monitoring plots at locations that had been classified as wet prairies before 2002, and in herbaceous communities at the Boone's Crossing unit. The purpose was to use existing and new data to identify, describe and map existing BMNFWR vegetation communities to the Association level of the United States National Vegetation Classification System (NVCS). This level of vegetation classification is suitable to describe vegetation communities at scales relevant to management prescriptions (The Nature Conservancy, 1994), and could be useful for planning objectives in the refuge's Comprehensive Management Plan.

\section{Study Area}

At the initiation of this project, Big Muddy National Fish and Wildlife Refuge included eight units along the Missouri River between Kansas City, Missouri and Saint Louis, Missouri (fig. 1). Most of the property in these units is in the flood plain of the Missouri River, though the units at Overton Bottoms and Saint Aubert Island also include small upland parcels.
Big Muddy units are distributed between two ecoregions (Bailey and others, 1994; Keys and others, 1995); three units in the Central Dissected Till Plains Section of the Prairie Parkland Province, and five units in the Ozark Highlands Section of the Eastern Broadleaf Forest Province (fig. 1). Ecological sections are regions ranging from hundreds to thousands of square miles in area and containing similarities in climate, geomorphology, primary soil groups, and potential vegetation formations (Cleland and others, 1997). Nigh and Schroeder (2002), identified ecoregional variation in current vegetation communities along the Missouri River at the ecological section scale. All of the sampled and mapped units are in the Ozark Highlands Section.

What follows is a summary of the acquisition history and status of tracts at the various units when they were acquired (unless otherwise indicated, agricultural production ceased when tracts were acquired):

- Lisbon Bottom (2,014 ac; 815 ha): 1,783 acres (89 percent) managed in the U.S. Department of Agriculture Natural Resource Conservation Service (USDANRCS) Wetland Reserve Program (WRP) when acquired (1995-97)

- Jameson Island (1,871 ac; 757 ha): 1,760 acres (94 percent) in the WRP when acquired (1995-98)

- Overton Bottoms (2,548 ac; 1031 ha):

- 1995-2000: 747 acres acquired, of which 483 acres (65 percent) were in the WRP

- 1998: the refuge began managing a 1,300 acre tract owned by the U.S. Army Corp of Engineers

- 2006: 501 acre tract added, of which 492 acres (98 percent) were in the WRP

- Saint Aubert Island (1,124 ac; 455 ha): land acquired between 1993 and 1997, none in the WRP

- Boone's Crossing (572 ac; 231 ha): land acquired in 2002 and 2004, none in the WRP

- Jackass Bend (844 ac; 342 ha):

- 444 acres acquired in 1997, of which 400 acres (90 percent) were in the WRP

- Approximately 400 acres have been added since, none in the WRP

- Agricultural production continued on approximately 40 acres until 2007

- Baltimore Bottom (1,626 ac; 658 ha):

- 1,490 acres acquired in 2002, of which 620 acres (42 percent) were in the WRP. Remaining 136 acres acquired after 2002 . 


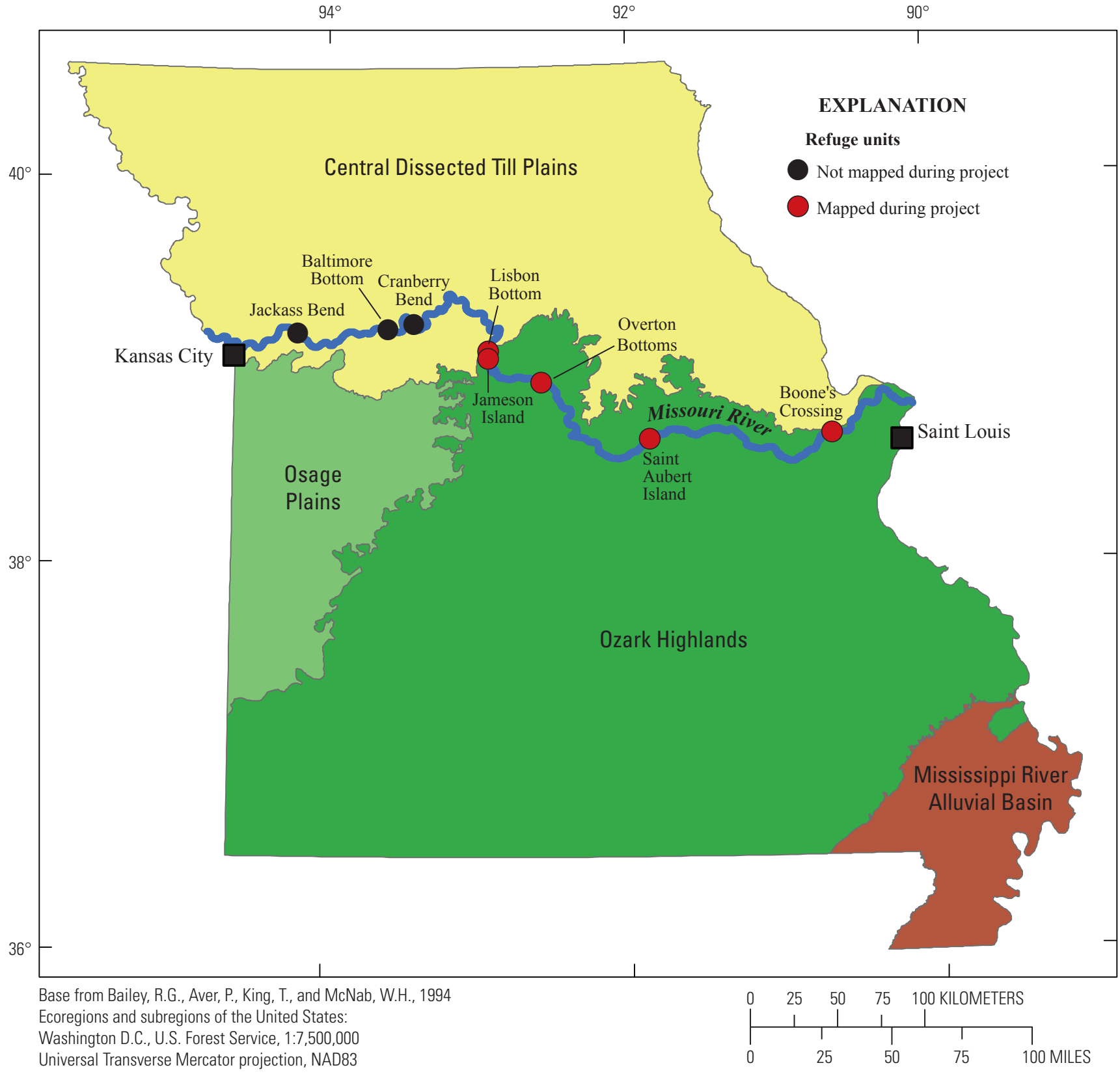

Universal Transverse Mercator projection, NAD83 Zone $15 \mathrm{~N}$

Figure 1. Big Muddy National Fish and Wildlife Refuge management units, Missouri, USA, 2006. 
- Agricultural production on about 50 percent until 2007 , with decreasing amounts until agricultural production ceased in 2009

- Cranberry Bend (599 ac; 242 ha):

- 85 acres in 1995, 460 acres in 2000, and 54 acres in 2008; none in WRP when acquired

- Row crops on approximately 30 percent of the unit until 2009

Habitat management has varied by unit on the refuge. All units have received herbicide applications to control exotic species, notably Japanese hops (Humulus japonicus) and garlic mustard (Alliaria petiolata) in wooded communities, and Johnson grass (Sorghum halepense) in herbaceous communities. As part of efforts to create side channels and shallow-water habitat, chutes have been constructed at Overton Bottoms and Jameson Island. These projects converted wide swaths of flood plain to riparian habitat, and dumped large quantities of dredge material onto the adjacent flood plains. Habitat management on about 10 percent of Overton Bottoms has included planting of hard mast tree species, seedings of Eastern gamagrass (Tripsacum dactyloides), plantings of prairie cordgrass (Spartina pectinata), and seeding of native forbs and grasses. Larger percentages of Baltimore Bottom and Cranberry Bend (about 18 and 40 percent, respectively) have received a similar mix of management treatments. About 40 acres at Jackass Bend have been planted in hard mast trees, of which about 15 acres also were planted with mixed native seeds and about 25 were planted with Virginia wildrye (Elymus virginicus).

\section{Methods}

\section{Identification of Potential Vegetation Communities}

Potential vegetation communities were identified that could occur within the refuge by conducting a literature review and interviewing ecologists familiar with the vegetation along the Missouri River. Potential vegetation refers to vegetation communities that are likely to naturally develop on a given site when ecological processes such as fire and flooding are present. In North America, presettlement vegetation is commonly considered to be representative of potential vegetation; however, management of the river and flood plain has altered much of the hydrologic regime that drove the historic distribution of plant communities. In this context, pre-settlement vegetation patterns may not accurately predict current potential vegetation.

Information concerning historic vegetation came primarily from Harlan (2002) who used General Land Office (GLO) land survey notes collected in the early 1800 s to create a coarse historic map for the Missouri River valley before large-scale settlement by non-indigenous Americans. Based on witness trees and general descriptions provided during the survey effort, Harlan classified vegetation as either forest, woodland, open woodland, prairie, or barren. Maps generated from Harlan's (2002) work showed that during the GLO survey, the areas that encompass the refuge units were dominated by woodlands. The Overton Bottoms unit was the only unit that contained more forested areas than woodlands during the GLO survey.

A more complete description of Missouri River riparian vegetation in western Missouri was conducted by Weaver (1960). Weaver's work discusses of the origin and development of streams, vegetation, soils, forests, swamps, marshes, and prairies on flood plains along the Missouri River. Weaver (1960) divided flood plains into two broad types; 1) low bottoms that occur near the river channel and are subject to occasional or frequent flooding, and 2) high bottoms that occur on wider and flatter parts of the flood plain, usually near bluffs. Low bottom forests contained cottonwood (Populus deltoides) and willows (Salix spp.). Better drained low bottom forest sites included trees such as white ash (Fraxinus americana), green ash (Fraxinus pennsylvanica), slippery elm (Ulmus rubra), American elm (Ulmus americana), boxelder (Acer negundo), hackberry (Celtis occidentalis), black walnut (Juglans nigra), sycamore (Platanus occidentalis), silver maple (Acer saccharinum), honey locust (Gleditsia triacanthos), and Kentucky coffeetree (Gymnocladus dioicus). High bottom forests occupied a minor part of the Missouri River bottoms, but species composition tended to resemble that found in forests on well-drained low flood plains. As defined by Weaver, swamps in the low bottoms contained a mix of bulrushes (Scirpus spp.), cattail (Typha spp.), reed (Phragmites australis), broadfruit bur-reed (Sparganium eurycarpum), arrowhead (Sagittaria latifolia), and water plantain (Alisma spp.). Marshes contained sedges (Carex spp.), rushes (Juncus spp.), spike rushes (Eleocharis spp.), rice cutgrass (Leersia oryzoides), reed canary grass (Phalaris arundinacea), and smartweeds (Polygonum spp.). Prairie occurred on the low and high bottoms. Low bottoms contained wet, coarse-grass prairies comprised of switchgrass (Panicum virgatum), Canada wildrye (Elymus canadensis), and prairie cordgrass (Spartina pectinata). Prairies containing big bluestem (Andropogon gerardii), little bluestem (Schizachyrium scoparium), Indiangrass (Sorghastrum nutans) and Eastern gamagrass (Tripsacum dactyloides) occurred on better drained soils on high bottoms. Low bottoms also contained abandoned river channels, lakes, ponds, marshes, sandbars, grasslands, and shrublands.

Historic vegetation appears to have varied by ecological section. Presettlement vegetation along the river within the Central Dissected Till Plains Section was predominantly wet prairie and marshes, with narrow bands of bottomland forests (Harlan, 2002; Nigh and Schroeder, 2002). In this section, the Missouri River flood plain is broad, a few miles to 10 miles wide, and is bordered by conspicuous bluff lines of adjacent loess hills. Within the Ozark Highlands Section, the Missouri River is bordered by limestone bluffs and the flood 
plain constricts to a few miles wide or less. Presettlement flood-plain vegetation in this section was mostly bottomland forests dominated by willow (Salix spp.), cottonwood (Populus deltoides), sycamore (Platanus occidentalis), elm (Ulmus spp.), silver maple (Acer saccharinum), and hackberry (Celtis spp.; Harlan, 2002; Nigh and Schroeder, 2002). Mixed-hardwood forests that included oak (Quercus spp.), sugar maple (Acer saccharum), black walnut (Juglans nigra), and hickories (Carya spp.) occurred on high terraces (Nigh and Schroeder, 2002). Though masked by anthropogenic disturbance (particularly agriculture), differences in flood-plain vegetation along the Missouri river at the ecological sections scale persist to this day (Nigh and Schroeder, 2002).

The primary source for information on existing and potential vegetation was the National Vegetation Classification System (NVCS; The Nature Conservancy, 1994). This system was developed with seven levels. The physiognomic levels (System, Class, Subclass, Group, and Formation) are a modification of the United Nations Educational, Scientific, and Cultural Organization (UNESCO) world classification of vegetation (Maybury, 1999). They are based on the physiognomic characteristics of the dominant vegetation, including whether communities are forested or herbaceous, and whether trees are broad-leaved or needle-leaved, deciduous or evergreen. The two lowest levels, Alliance and Association, are determined by floristic composition and are described using procedures outlined in Grossman and others (1998). Classes in the Alliance and Association levels are defined by the dominant and characteristic species found within them. The NVCS has been adopted through the Formation level by the Federal Geographic Data Committee for use by all U.S. federal agencies.

NatureServe, in cooperation with numerous conservation agencies and organizations, maintains and updates all vegetation descriptions in the NVCS (NatureServe, 2009). A relevant published reference stemming from this effort is The Plant Communities of the Midwest (Faber-Langendoen, 2001). Other published works that informed the analysis include The Terrestrial Natural Communities of Missouri (Nelson, 2005), and the Edward "Ted" and Pat Jones - Confluence Point Station Park Revegetation and Restoration Plan (McCarty and others, 2004). These documents provided comprehensive descriptions of potential vegetation communities and NVCS associations that may occur along the Missouri River. These sources were augmented with information gathered from Timothy Nigh (oral and written communs., 2006). Mr. Nigh is a Resource Scientist with the Missouri Department of Conservation, a local expert on Missouri vegetation, and a contributor to the Plant Communities of the Midwest (Faber-Langendoen, 2001). At about the approximate time of the creation of BMNFWR, Mr. Nigh and then refuge biologist Maureen Gallagher had identified the potential vegetation types that could occur on the refuge. This list was used in conjunction with presettlement references cited above to compile a complete list of potential NVCS vegetation communities for the refuge.

\section{Data Collection}

\section{2-04 Previously Collected Vegetation Data}

Between 2002 and 2004 a survey of bottomland vegetation communities was conducted for a resident and migratory songbird study and a study of the ecology and rehabilitation of flood-plain forests (Bezzerides and others, 2003; Young, 2004). Vegetation data were collected at points stratified by broad vegetation types: early successional forests, mature forests, or wet prairies (broadly defined to include all nonwooded areas on the flood plain). Within a 0.10 ha (17.85 meter (m) radius) circular plot, individual species and total vegetative cover were estimated in each of five strata (upper-upper canopy, upper canopy, mid-canopy, shrub canopy, and groundflora canopy). A variable-radius subplot was used to collect data necessary to estimate stem density and basal area within each stratum (excluding ground flora). Variable-radius plots were used to facilitate data collection within habitats with high variation in stem density. Plot area for each stratum was determined by the smallest plot size -0.10 ha (radius: $17.85 \mathrm{~m}), 0.0625$ ha $(14.1 \mathrm{~m}), 0.025$ ha $(8.92 \mathrm{~m}), 0.006$ ha $(4.46 \mathrm{~m})$, or $0.0016 \mathrm{ha}(2.23 \mathrm{~m})$ - within which 50 stems were recorded. Each stem was recorded as live or dead, identified to species and its diameter at breast height (DBH, $1.4 \mathrm{~m}$ above the ground) was measured to the nearest 0.5 centimeter $(\mathrm{cm})$. Additional environmental data collected at each sample point included soil texture, if water was present, habitat type (forest or open), and global positioning system (GPS) coordinates.

\section{New Data}

The sampling area for new data included only those areas that had been delineated as wet prairie before sampling in 2002, as well as herbaceous communities at the Boone's Crossing unit (acquired in 2007). At Boone's Crossing, herbaceous communities were delineated using 2006 USDA National Agricultural Imagery Program (NAIP) data obtained from the Missouri Spatial Data Information Service (MSDIS, 2006). Data collection began in July, 2007, with the bulk of the sampling occurring between August 22 and October 12 . Sampling was delayed because of late spring (May and June) flooding, which prevented access to many of the sites and delayed plant development, hindering identification in the field until approximately August 1.

GIS data and handheld GPS receivers were used to find the approximate (within $10 \mathrm{~m}$ ) locations of plots sampled in 2002 and 2003. At Boone's Crossing, points were randomly located within each herbaceous polygon delineated on NAIP photos. Magellan (Thales) ProMark 3 GPS receivers were used with an external NAP100 antenna (Magellan, San Dimas, Calif.). This system achieves submeter, post-processed accuracy, well within the needs of current management goals and the goals of this research. The location of the new plot center was recorded by noting the height of the antenna above the ground and taking GPS reading for the duration of plot 
vegetation sampling, usually between 20 minutes and one hour.

Plot center was permanently marked (fig. 2). A 10-foot (ft) section of ultraviolet (UV) radiation-resistant, polyvinyl chloride (PVC) electrical conduit was cut approximately $0.6 \mathrm{~m}$ $(2 \mathrm{ft})$ from the flared end. A fifteen $(15) \mathrm{cm}$ piece of $3 / 8$-inch rebar was placed through a hole drilled just below the flared end. A piece of corrosion resistant wire was used to secure the rebar and to attach a corrosion resistant tag engraved with the plot name. This item was then driven into the ground until the rebar was flush with the ground, with the flared end of conduit sticking up. The remaining segment of conduit (approximately $2.4 \mathrm{~m}$ in length) was then nested in the exposed, flared end of the buried conduit to enable rapid relocation of plot center. The rebar is included to allow for relocation of the plot center using a metal detector, should the more visible portions of the monument become lost or obscured (for example, as a result of flooding).

To sample vegetation, the Beyond North American Weed Management Association (NAWMA) plot (Stohlgren and others, 2008) was used, a modified version of multiscale circular plots used in the U.S. Forest Service Inventory and Analysis program (Frayer and Furnival, 1999). The Beyond NAWMA plot is one of many recommended by the National Institute of Invasive Species Science (NIISS, 2007) for monitoring invasive nonnative plant species, a secondary objective of the 2007 sampling. The Beyond NAWMA Plot (fig. 3) is a $7.32 \mathrm{~m}$ fixed-radius plot, with a total sample area of 168 square meters $\left(\mathrm{m}^{2}\right)$. Three transect lines are located at azimuths of 30 degrees $\left.{ }^{\circ}\right), 150^{\circ}$, and $270^{\circ}$ from plot center, radiating out to the plot edge. Transects are temporarily flagged at the outer terminus to delineate the perimeter of the plot. Vegetation quadrats $\left(1 \mathrm{~m}^{2}\right)$ are located on the clockwise side of each transect with

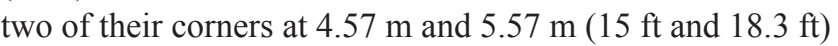
along the transects. These corners were marked using survey flags with metal pins.

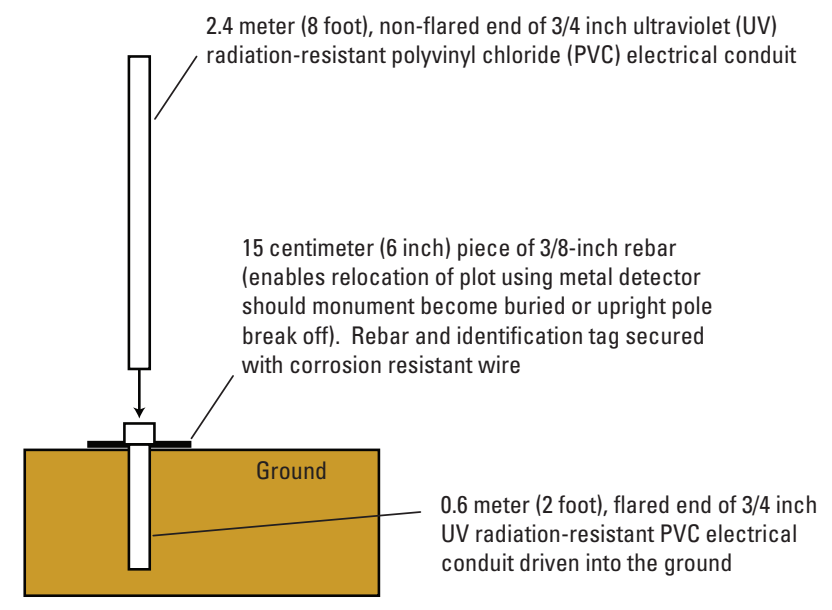

Figure 2. Monumentation used to permanently mark plots.

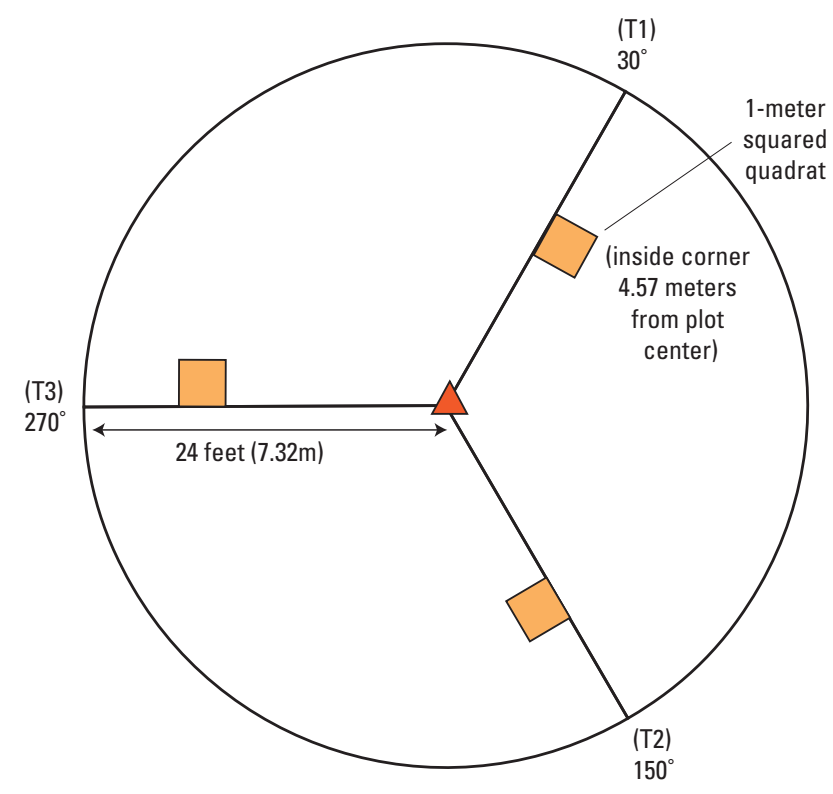

Figure 3. Beyond North American Weed Management Association (NAWMA) plot design used during 2007 sampling.

Within each quadrat, all herbaceous species and woody species providing foliar cover below one meter were identified and the foliar cover of each was estimated to the nearest 1 percent. Cover was estimated to the nearest 1 percent for each of the following microhabitat variables: dead wood, dung, fungus, lichen, litter/duff, live tree bole and visible roots, mineral soil/sediment, moss, road, rock, standing/flooded water, stream, and trash/junk . Within the $7.32 \mathrm{~m}$ radius plot, all identified species that were not previously recorded in the quadrats were recorded as present. All woody stems were identified to species and the DBH was measured. Total canopy cover for the plot was estimated, and the following environmental data were recorded for the plot: slope, aspect, elevation, distance to water, distance to road, and distance to crops. Notation was also made of any human or other animal disturbance. Photographs were collected from the plot center oriented along each of the three transects; included within each photograph was an indication of the plot and transect. The primary references for plant identification were Flora of Missouri (Steyermark, 1963), and Steyermark's Flora of Missouri Volume 1 (Yatskievych, 1999) and Volume 2 (Yatskievych, 2006). Plant nomenclature followed the USDA-PLANTS database (USDA, NRCS, 2009).

Data were collected using the EcoNab data collection tool (available free from the NIISS website) on handheld PDAs with the Palm ${ }^{\mathrm{TM}}$ operating system. This program includes features designed to ensure data quality, including requiredentry data fields, a subprogram to aid in the management and identification of unknown species, and regionally customizable look-up tables for species. Data were downloaded to and managed within the VegSurvey Database (.mdb format), also available free from the NIISS website (www.niiss.org). 


\section{Data Analysis}

Three primary metrics derived from field data were used for data analysis: percent cover data for all species, and density (stems/ha) and basal area $\left(\mathrm{m}^{2} / \mathrm{ha}\right.$ ) for woody species summarized by canopy position. Before multivariate analyses, plots were subjectively assigned to a NVCS association by comparing field observations and plot data to NVCS association descriptions and information gleaned from local experts on flood-plain communities. Plots were assigned to the association that best matched current conditions, with a secondary designation for those plots that were difficult to classify.

Discrepancies were noticed in how field crews assigned stems to strata between 2002 and 2004; therefore, information concerning specific strata and woody stems were not retained for multivariate analyses. For example, occasionally a plot with most of its stems assigned to the upper-canopy in 2002 would have virtually no stems assigned to this stratum in subsequent sampling years, but would instead have nearly all of its stems assigned to the mid-canopy. These types of discrepancies point to the potential for sampling biases between sample events and suggest sampling inconsistency between years; therefore, for multivariate analyses, all woody stems measurements from all strata were combined to generate plot-level (rather than strata-specific) basal area and density estimates for each species. This was not a concern for ground flora data.

Multivariate analysis was conducted in three stages using PC-ORD V. 5.0 (McCune and Mefford, 1999; McCune and Mefford, 2006). First, outlier analysis was used to identify samples with potentially anomalous values for one or more species. Second, Non-metric Multidimensional Scaling (NMS) was used to examine similarities between plots and to identify species' abundances that were driving the relations between communities. NMS was also used to identify and potentially reclassify plots that did not match other plots assigned the same NVCS association. Finally, Multi-Response Permutation Procedure (MRPP) was used as a statistical test for differences between groups of plots based on the NVCS type assigned.

A standard initial procedure during multivariate analysis is to identify outliers, sample units with extreme values for one or more variables or with unusual combinations of values for multiple variables. For example, extreme values for particular variables can skew data, masking the effects of other variables and thereby limiting the interpretive value of multivariate analyses (McCune and Grace, 2002). As another example, the extreme values for certain variables may also identify a particular group of sample units as a unique class within the data set. Possible solutions to outliers can include, but are not limited to 1) adjustment of the complete data set using standard data transformation, such as conversion to logarithmic scale; 2) removal of anomalous sample units from further analysis because they hinder interpretation of data for other sample units; or 3) retaining them in further analyses because they represent a unique type and there is little reason to suspect that inclusion hinders interpretation of multivariate analyses. Outlier analysis was based on the Sorensen (BrayCurtis) distance of each plot from mean distance between sample units, and sample units were flagged that were more than two standard deviations away from the mean. Once outliers were identified, plots were reviewed to determine how outliers or the larger data set should be treated.

Once outlier analyses were performed, NMS was used to explore the relation between plots and assigned NVCS associations. NMS is an iterative ordination process to find the best fit of data in a reduced number of dimensions and has been described as the most effective ordination method for ecological community data (McCune and Grace, 2002). The advantages for NMS are: 1) avoiding the assumption of linear relations among variables, 2) ranking distances are used to linearize distances measured in species and environmental space, and 3 ) it allows the use of any distance measure or relativization (McCune and Grace, 2002). Analysis using NMS yields a measure of final stress (lack of fit; scale of 1 to 100) and a graphical output of plots, species, or both according to ordination scores. When considering the NMS graphical output, the proximity of plots to one another reflects their similarity in terms of species composition and abundance. As with other ordination techniques, one also can measure and represent the relation of individual species to the data structure using correlation coefficients $(r)$ for each species relative to each axis. The sum of the squared $r$ values (multiple $r^{2}$ ) represents the amount of variation in the data explained by that species' abundance values. NMS was used to 1) assess the similarity of plots within the various types to their assigned classification, 2 ) identify plots that may have been poorly classified, and 3) identify the species' abundance measures most correlated with the data structure, as indicated by the multiple $r^{2}$. NMS analyses were conducted on overstory density and basal area for forested plots and on groundflora cover data for herbaceous plots.

Subsequent to outlier and NMS analyses and adjustments made to community classification based on them, MultiResponse Permutation Procedure (MRPP) was used to test for differences between vegetation communities based on their final classification (McCune and Grace, 2002). Because MRPP is a nonparametric analysis method, it can handle nonlinear relations or data with skewed frequency distributions - the types of data commonly encountered in vegetation community analysis (McCune and Grace, 2002). MRPP analysis yields the output variable $A$ (the chance-corrected withingroup agreement), which describes the measure of similarity between sample units within a group; the test statistic $T$, which describes the separation between groups; and a $p$-value for $T$. The variable $A$ ranges from 0 (heterogeneity within groups equals expectations by chance) to 1 (all items within a group are identical). For ecological data, values for $A$ are usually below 0.1 , while $A$ values of greater than 0.30 can safely be interpreted as indicating high similarity within analyzed groups (McCune and Grace, 2002). For the test statistic $T$, the more negative value for $T$ indicates a stronger separation 
between groups. The $p$-value indicates how likely differences between groups (the T statistic) could be because of chance.

\section{Map Production}

\section{Community Delineation}

Vegetation communities were delineated in ArcMap 9.3.1 using NAIP photos obtained from the MSDIS. These photos were true-color for 2002, 2005, 2006, and 2007 and were color-infrared for 2003. U.S. Army Corps of Engineers true color aerial photos from 2000 were also used. Differences and similarities in color and texture were used to delineate polygons of different vegetation types on the photos. Existing vegetation data points were overlaid on the NAIP images to classify polygons and identify image signatures for vegetation communities. The refuge provided additional spatial data layers that documented past management on specific refuge units. These data assisted in identifying patterns that were caused by management actions, such as, hard mast tree plantations or warm season grass plantings. A draft vegetation community map was completed in the spring of 2008.

\section{Final Community Polygon Classification and Boundary Adjustment}

Because of an exceptionally wet growing season in 2008, refuge units were inundated most of the growing season and vegetation was unable to develop enough for plant community identification; therefore, work was delayed for one year, and final map classification data were collected during the 2009 growing season. Further, the 2008 flooding combined with extensive flooding in early 2009 created substantial changes in the vegetation between the last year of data collection (2007) and the production of the map. This was particularly true in low lying areas, where persistent ponding of water caused changes from communities dominated by weedy native species or non-native species to ephemeral wetlands that were dominated by native hydrophilic species.

Rather than adopt accuracy assessment procedures typically used in the production of remotely-sensed maps, sampling resources were used during the final stage of map production to visit and classify as many mapped polygons as possible and to adjust polygon boundaries where field observations supported doing so. Three factors contributed to this decision. First, the primary goal was a finished product that gave the most accurate representation of the current vegetation on the refuge, rather than a map with known and suspected errors as is produced by standard remote sensing efforts. Second, accuracy assessments are only meaningful if applied to areas where there is a reasonable expectation that the map incorporates data and information relevant to all, or nearly all, mapped classes. During this study, resource limitations prevented the collection of plot data for many community types (particularly those in the uplands), such that this criterion for accuracy assessment was not met. Finally, observations in 2007, 2008 and 2009 indicated that flooding during those years was causing rapid change in herbaceous and forested communities on the flood plains, such that even if the preliminary map accurately reflected conditions from when the data were collected it was unlikely to reflect conditions at the end of the project.

Once a preliminary map had been created, each previously unsampled polygon was populated with a classification point at its approximate center. Sampling crews then visited each map classification point, and assigned the polygon to a given community type based on comparisons between: 1) field observations, and 2) local and global NVCS descriptions developed by NatureServe (2009). Routes were planned to enable the field crew to visit previously sampled polygons and assess the accuracy of classification based on plot data without actually revisiting all sample points from previous years. If the previous classification based on plot data seemed incorrect or no longer appropriate because of changes in vegetation, a new classification was assigned to the polygon. Additionally, 2009 field observations and handheld GIS data loggers were used to identify adjustments that should be made to community boundaries. All field data were then used to adjust the final map within the ArcMap GIS platform.

\section{Results}

\section{Vegetation Communities of Big Muddy National Fish and Wildlife Refuge}

A review of literature concerning historic, current, and potential vegetation communities of the Missouri River flood plain identified 25 potential bottomland vegetation associations that had a high likelihood of occurring within the refuge (table 1). Many of these communities are now extremely rare within Missouri as a result of conversion to agriculture and river management. Primary among these are nonforested wetlands, wet-mesic prairies, and bottomland oak woodlands and forests, many of which were not encountered during this study, though they potentially exist within the Missouri River flood plain (table 1). During data collection for this project, communities were identified that tentatively matched the NVCS descriptions for 11 of these types; 6 forests, 1 woodland, 1 shrubland, and 3 herbaceous communities. Existing or newly collected plot data were available for four of the above forests, the woodland, the shrubland, and two of the herbaceous communities. Plot data were also available for three ruderal communities not described by the NVCS; Herbaceous Old Fields, Woody Old Fields, and Johnson Grass communities.

During the project, 6 upland oak forest types, 2 bottomland hardwood types, and 1 herbaceous community type described by the NVCS were encountered (table 1), but no plot data were collected. Local descriptions (appendix 1) for these types are based on observations made during map 
Table 1. Existing and potential National Vegetation Classification System (NVCS) Associations at Big Muddy National Fish and Wildlife Refuge.

[NC, not considered; Y, yes; ?, status in Missouri uncertain; N, no; bold text indicates communities encountered during project.]

\begin{tabular}{|c|c|c|c|c|}
\hline NVCS common name & NVCS code & Nelson' type & $\begin{array}{c}\text { On } \\
\text { refuge }^{2}\end{array}$ & $\begin{array}{c}\text { In } \\
\text { Missouri }^{3}\end{array}$ \\
\hline \multicolumn{5}{|c|}{ Forest } \\
\hline White Oak-Red Oak-Sugar Maple Mesic Forest & CEGL002058 & Dry-Mesic Loess/Glacial Till Forest & $\mathrm{NC}$ & $\mathrm{Y}$ \\
\hline White Oak/Dogwood Dry-Mesic Forest & CEGL002066 & Dry-Mesic Loess/Glacial Till Forest & $\mathrm{NC}$ & $\mathrm{Y}$ \\
\hline White Oak-Mixed Oak Dry-Mesic Alkaline Forest & CEGL002070 & Dry-Mesic Limestone/Dolomite Forest & $\mathrm{NC}$ & $\mathrm{Y}$ \\
\hline Black Oak-White Oak-Hickory Forest & CEGL002076 & Dry-Mesic Loess/Glacial Till Forest & $\mathrm{NC}$ & $\mathrm{Y}$ \\
\hline Ozark Red-cedar-Hardwood Forest & CEGL004803 & Dry Limestone/Dolomite Woodland & $\mathrm{NC}$ & $?$ \\
\hline \multicolumn{5}{|c|}{ Temporarily Flooded } \\
\hline Midwestern Cottonwood-Black Willow Forest & CEGL002018 & Riverfront Forest & $\mathrm{Y}$ & $\mathrm{Y}$ \\
\hline Black Willow Riparian Forest & CEGL002103 & Riverfront Forest & $\mathrm{Y}$ & $\mathrm{N}$ \\
\hline Pin Oak Mixed Hardwood Depression Forest & CEGL002432 & Wet-Mesic Bottomland Forest & $\mathrm{N}$ & $\mathrm{Y}$ \\
\hline Bur Oak-Swamp White Oak Mixed Bottomland Forest & CEGL002098 & Wet-Mesic Bottomland Forest & $\mathrm{N}$ & $\mathrm{Y}$ \\
\hline Box-elder Floodplain Forest & CEGL005033 & Wet-Mesic Bottomland Forest & $\mathrm{Y}$ & $\mathrm{Y}$ \\
\hline \multicolumn{5}{|c|}{ Woodland } \\
\hline Cottonwood Floodplain Woodland & CEGL002017 & Wet-Mesic Bottomland Woodland & $\mathrm{Y}$ & $\mathrm{Y}$ \\
\hline Burr Oak Bottomland Woodland & CEGL002140 & Wet-Mesic Bottomland Woodland & $\mathrm{N}$ & $\mathrm{Y}$ \\
\hline \multicolumn{5}{|c|}{ Shrubland } \\
\hline Sandbar Willow Shrubland & CEGL008562 & Riverfront Shrubland & $\mathrm{Y}$ & $\mathrm{Y}$ \\
\hline Northern Buttonbush Swamp & CEGL002190 & Shrub Swamp & $\mathrm{N}$ & Y \\
\hline \multicolumn{5}{|c|}{ Herbaceous } \\
\hline Water lily Aquatic Wetland & CEGL002386 & Freshwater Marsh & $\mathrm{N}$ & $\mathrm{Y}$ \\
\hline River Bulrush Marsh & CEGL002221 & Freshwater Marsh & $\mathrm{N}$ & $\mathrm{Y}$ \\
\hline Central Midwest Sedge Meadow & CEGL005272 & Freshwater Marsh & $\mathrm{N}$ & $\mathrm{Y}$ \\
\hline Midwest Ephemeral Pond & CEGL002430 & Freshwater Marsh & $\mathrm{Y}$ & Y \\
\hline Eastern Great Plains Saline Marsh & CEGL002043 & Saline Seep & $\mathrm{Y}$ & $\mathrm{Y}$ \\
\hline Great Plains Acidic Seep & CEGL002235 & Acid Seep & $\mathrm{Y}$ & $?$ \\
\hline \multicolumn{5}{|c|}{ Sparse Herbaceous } \\
\hline Riverine Sand Flats & CEGL002049 & Sandbar/Stream-bank/Riverbank & $\mathrm{Y}$ & $\mathrm{Y}$ \\
\hline
\end{tabular}

${ }^{1}$ Nelson, P.W., 2005, The Terrestrial Natural Communities of Missouri: The Missouri Natural Areas Committee, The Missouri Department of Natural Resources, Jefferson City, Missouri, $550 \mathrm{p}$.

${ }^{2}$ Unpublished document by Timothy Nigh (Resource Scientist, Missouri Department of Conservation) and Maureen Gallagher (Biologist, formerly with Big Muddy National Fish and Wildlife Refuge).

${ }^{3}$ NatureServe, 2009, NatureServe Explorer: An online encyclopedia of life [web application], Version 7.1: NatureServe, Arlington, Virginia, accessed 28 December, 2009, www.natureserve.org/explorer. 
production and familiarity with each type from previous work within the study area. Eleven additional water and cultural feature classes (such as ponds and roads) were identified and mapped, some of which are described in appendix 1.

The locations of identified and mapped communities are documented in spatial data collected during final map production, during which nearly every mapped polygon was visited and classified. Table 1 lists potential NVCS community types for the refuge and indicates their suspected status in Missouri (NatureServe, 2009) and on the refuge (T.A. Nigh, Resource Scientist, Missouri Department of Conservation, oral and written communs., 2006-07; M. Gallagher, Biologist, Big Muddy National Fish and Wildlife Refuge, 2006, unpub. data). Table 2 lists ruderal communities and other cultural features encountered during this study.

\section{Analyses of Plot Vegetation Data}

Communities were classified by comparing plot data and field observations made during 2007 and 2009 to NVCS association descriptions (Faber-Langendoen, 2001; NatureServe, 2009), statewide community descriptions (Nelson, 2005) and incorporating the opinions of local experts on Missouri River flood-plain communities (T.A. Nigh, Resource Scientist,
Missouri Department of Conservation, oral and written communs., 2006-07; M. Gallagher, Biologist, Big Muddy National Fish and Wildlife Refuge, unpub. data). Multivariate analyses were based on each plot's most recent data $(2002,2003,2004$, or 2007). Analyses of woody communities were based on plotlevel basal area and density data for woody species; analyses of herbaceous communities were based on ground flora cover estimates. In subsequent sections, communities currently recognized by the NVCS are referred to by their NVCS common name, followed by their NVCS code, which is formatted as CEGL00\#\#\#\# for terrestrial communities (NatureServe, 2009).

\section{Wooded Communities}

Comparisons of data and field observations to NVCS description for potential communities within the study area (Faber-Langendoen, 2001; NatureServe, 2009) provided for an initial identification of eight woody community types in bottomlands for which there were plot data. These include two expressions (mature and immature) of the Midwestern Cottonwood-Black Willow Forest (CEGL002018). The identified communities share many species, with cottonwood (Populus deltoides), willow (Salix spp.), and snags (standing dead woody stems with a diameter at breast height) being

Table 2. Existing ruderal vegetation associations and other mapped features at Big Muddy National Fish and Wildlife Refuge.

\begin{tabular}{|c|c|}
\hline Community name & Comment \\
\hline \multicolumn{2}{|r|}{ Ruderal communities } \\
\hline Herbaceous old field & $\begin{array}{l}\text { Found in bottoms; Extremely variable; succeeding toward Polygonum wetland (CEGL002430) in low-lying } \\
\text { areas }\end{array}$ \\
\hline Fescue field & Upland communities dominated by tall fescue (Festuca arundinacea) with mixed forbs common to old fields \\
\hline Bottomland woody old field & $\begin{array}{l}\text { Appears to be succeeding toward either the Central Green Ash-Elm-Hackberry Forest (CEGL002014) or } \\
\text { the Ash-Oak-Sycamore Mesic Bottomland Forest (CEGL00410) }\end{array}$ \\
\hline Johnson grass & Dominates in many drier old fields in the flood plain \\
\hline \multicolumn{2}{|r|}{ Other features } \\
\hline Levee & $\begin{array}{l}\text { Usually dominated by tall fescue (Festuca arundinacea) and managed (typically mowed) to maintain access. } \\
\text { Does not include abandoned levees with high woody stem density }\end{array}$ \\
\hline Pond & $\begin{array}{l}\text { Human-constructed water feature; may include Polygonum wetland (CEGL002430) or Riverine Sand Flats } \\
\text { (CEGL002049) at margins }\end{array}$ \\
\hline \multicolumn{2}{|l|}{ Railroad } \\
\hline River & Water adjacent to main channel \\
\hline \multicolumn{2}{|l|}{ Road } \\
\hline Row crop & Agriculturally managed, most likely for corn or soybeans \\
\hline Scour & $\begin{array}{l}\text { Naturally occurring pond; likely includes Polygonum wetland (CEGL002430) or Riverine Sand Flats } \\
\text { (CEGL002049) at margins }\end{array}$ \\
\hline Utility right-of-way & Shrubby or herbaceous depending on time since last vegetation control effort \\
\hline
\end{tabular}


particularly abundant in all community types (table 3). Cottonwood was found in 89 percent of the 132 wooded plots, while willows and snags were found in 73 percent of the plots. Other frequently encountered species in forested plots included boxelder (Acer negundo), silver maple (Acer saccharinum), ash (Fraxinus spp.), and sycamore (Platanus occidentalis). The low species diversity across the study area facilitated classification, as shifts in dominance from one or two species to a few other species were easily identified. In many cases, the absence of a given species, such as cottonwood, was important in determining which association type a plot represented.

The high frequency (0.73) and densities of snags is consistent with common patterns of stand development. Forests progress through four stages during development: stand initiation, stem exclusion, understory reinitiation, and old growth (Oliver and Larson, 1990). During the stand initiation stage, trees, shrubs, and herbaceous vegetation invade disturbed land and begin to colonize the open ground. During the stand initiation stage plants grow to occupy all of the available growing space and stem densities can become extremely high. Once all of the growing space is occupied, stands enter the stem-exclusion stage, in which plants compete for light, water, nutrients, and physical space. The stem-exclusion stage is characterized by an increase in mortality (Oliver and Larson, 1990) and, therefore, a higher density of dead stems.

As the refuge acquired land from willing sellers after the 1993 and 1995 floods, many parcels of land on the refuge entered the stand initiation stage. The data suggest that during the 2002-04 sample period, many of the forested stands had entered the stem-exclusion stage, accounting for the high frequency and density of snags in the data from that period. Evidence gathered during 2007 and 2009 support that stem exclusion was continuing. This stand-wide mortality is being augmented by mortality caused by flooding, the effects of which tend to be patchily distributed within established stands because of variation in flood intensity (depth, water speed and duration) as determined by landscape characteristics.

The most frequently encountered woody community was Midwestern Cottonwood-Black Willow Forest (CEGL002018), which accounted for 68 percent of all the forested plots (91 out of 134; table 3 ). This forest type is dominated by cottonwood (Populus deltoides) with varying amounts of willow (Salix spp.). This community had a wide range of expression (appendix 1), from newly established thickets, to young stands in the stem-exclusion stage of development, to stands of mature cottonwoods that had established on unprotected flood plains where there was no agricultural activity before acquisition by the refuge. It also included small areas dominated by black willow (Salix nigra) that were tentatively classified as the Black Willow Riparian Forest (CEGL002103). Newly established stands had the highest stem densities, the greatest abundance of Salix spp., and sparse ground flora resulting from shading because of the dense woody stem growth of stand initiation. In 10 to 15 year-old stands entering the next stage of forest development, stem exclusion tends to eliminate Salix interior as it becomes shaded by the higher growing cottonwoods and black willow (though these species become less dense, too). Stem mortality increases the amount and the spatial heterogeneity of sunlight reaching the ground flora, increasing its diversity. Mature cottonwood forests have a more complex structure, with multiple canopy layers where cottonwood shares dominance with other species, a variable shrub layer, and diverse ground flora. Mature Midwestern Cottonwood-Black Willow Forests (CEGL002018) and Black Willow Riparian Forests (CEGL002103) were retained as unique types for multivariate analysis.

Cottonwood Floodplain Woodland (CEGL002017) accounted for 16 percent (21 out of 134) of the plots dominated by woody species (table 3). The NVCS description emphasizes a few characteristics about this type: 1) canopy of cottonwoods (Populus deltoides) and other species with a cover below 60 percent, or if higher, 2) a poorly developed understory and shrub layer, and 3) a diverse ground flora dominated by bottomland grasses, such as prairie cordgrass (Spartina pectinata) and sedges (Carex spp.). For classification purposes, it was recognized that ground flora had not had sufficient time to establish and diversify since acquisition by the refuge, and that the structure of the canopy was dynamic in relatively young stands of cottonwood. This is particularly true in areas where flooding and stem exclusion appear to be pushing succession toward a woodland type; therefore, when classifying communities as the Cottonwood Floodplain Woodland, more attention was given to structure and cover in the upper strata with less emphasis on the composition of the ground flora. Generally, the woodland classification was reserved for those communities with less than 60 percent cover and poorly developed understory and shrub layers.

Sandbar Willow Shrubland (CEGL008562) represented 5 (4 percent) out of 132 wooded plots sampled (table 3). Salix interior was the dominant species in these communities, with lesser and more variable amounts of Salix nigra and Salix caroliniana. Cottonwood (Populus deltoides) was at most co-dominant with Salix, and even when fully developed, this community was characterized by a low canopy (about $5 \mathrm{~m}$ ) comprised of small diameter stems. These characteristics differentiate the sandbar willow shrubland from the woodland and forest communities and are consistent with the NVCS Association description. Despite high densities of willow and cottonwood, the sandbar willow shrublands have low basal areas for these species (table 3). The ground flora layer is variable in structure and composition, ranging from little or no vegetation below dense thickets of willow to almost complete herbaceous cover in openings resulting from uneven establishment of woody species or flooding.

Box-elder Floodplain Forests (CEGL005033) and Silver Maple-Elm Forests (CEGL002586) were identified on 11 (8 percent) and 2 ( 2 percent) of 132 wooded plots (table 3 ). Following the NVCS description for each type, these classifications were reserved for sites dominated (greater than 50 percent cover) by Acer negundo and Acer saccharinum, respectively. Other frequently abundant species in both types include 


\section{Vegetation Communities at Big Muddy National Fish and Wildlife Refuge, Missouri}

Table 3. Woody species measures for woody dominated vegetation associations as classified based on field data and observations.

[ha, hectare; $\mathrm{m}^{2}$, square meter; CEGL00xxxx, National Vegetation Classification System (NVCS) code; $n$, sample size; Species with basal area less than 0.001 $\mathrm{m}^{2} /$ ha are excluded.]

\begin{tabular}{|c|c|c|c|}
\hline Scientific name & Mean density (stems/ha) & Mean basal area $\left(\mathrm{m}^{2} / \mathrm{ha}\right)$ & Frequency \\
\hline \multicolumn{4}{|c|}{ Cottonwood Floodplain Woodland-CEGL002017 $(n=21)$} \\
\hline Populus deltoides Bartr. ex Marsh. & $1,287.3$ & 4.942 & 0.95 \\
\hline Salix interior Rowlee & $1,699.0$ & 1.874 & .41 \\
\hline Unknown snag & 941.5 & .289 & .18 \\
\hline Salix nigra Marsh. & 80.0 & .289 & .09 \\
\hline Platanus occidentalis L. & 10.8 & .074 & .09 \\
\hline Morus L. & 2.7 & .008 & .05 \\
\hline Salix caroliniana Michx. & 1.8 & .001 & .05 \\
\hline Juniperus virginiana $\mathrm{L}$. & 8.1 & .001 & .09 \\
\hline Prunus americana Marsh. & 8.1 & .001 & .05 \\
\hline \multicolumn{4}{|c|}{ Black Willow Riparian Forest-CEGL002103 $(n=7)$} \\
\hline Populus deltoides Bartr. ex Marsh. & 442.9 & 2.661 & 1.00 \\
\hline Salix interior Rowlee & 457.1 & 1.373 & .86 \\
\hline Salix L. & 120.0 & .511 & .29 \\
\hline Acer negundo L. & 51.4 & .057 & .29 \\
\hline Morus L. & 14.3 & .015 & .29 \\
\hline Vitis L. & 62.9 & .004 & .43 \\
\hline Celtis L. & 5.7 & .002 & .14 \\
\hline Platanus occidentalis L. & 5.7 & .001 & .14 \\
\hline \multicolumn{4}{|c|}{ Silver Maple Floodplain Forest-CEGL002586 $(n=2)$} \\
\hline Acer saccharinum $\mathrm{L}$. & 195.0 & 31.337 & 1.00 \\
\hline Campsis radicans (L.) Seem. ex Bureau & 5.0 & .004 & .50 \\
\hline \multicolumn{4}{|c|}{ Mature Cottonwood-Willow Forest-CEGL002018 $(n=5)$} \\
\hline Populus deltoides Bartr. ex Marsh. & 50.8 & 12.730 & 0.60 \\
\hline Acer negundo L. & 284.9 & 6.188 & 1.00 \\
\hline Acer saccharinum $\mathrm{L}$. & 78.9 & 4.588 & .80 \\
\hline Platanus occidentalis $\mathrm{L}$. & 95.1 & 3.562 & 1.00 \\
\hline Carya Nutt. & 9.6 & 2.576 & .40 \\
\hline Morus L. & 196.0 & 1.713 & 1.00 \\
\hline Unknown snag & 96.7 & 1.620 & 1.00 \\
\hline Vitis L. & 313.5 & 0.749 & 1.00 \\
\hline Salix L. & 2.0 & .304 & .20 \\
\hline Ulmus L. & 13.1 & .126 & .40 \\
\hline Toxicodendron radicans (L.) Kuntze & 49.2 & .072 & .60 \\
\hline Celtis L. & 6.0 & .065 & .20 \\
\hline Cornus L. & 33.6 & .020 & .40 \\
\hline Campsis radicans (L.) Seem. ex Bureau & 19.2 & .012 & .20 \\
\hline
\end{tabular}


Table 3. Woody species measures for woody dominated vegetation associations as classified based on field data and observations.

[ha, hectare; $\mathrm{m}^{2}$, square meter; CEGL00xxxx, National Vegetation Classification System (NVCS) code; $n$, sample size; Species with basal area less than 0.001 $\mathrm{m}^{2} /$ ha are excluded.]

\begin{tabular}{|c|c|c|c|}
\hline Scientific name & Mean density (stems/ha) & Mean basal area ( $\left.\mathrm{m}^{2} / \mathrm{ha}\right)$ & Frequency \\
\hline \multicolumn{4}{|c|}{ Sandbar Willow Shrubland-CEGL008562 $(n=5)$} \\
\hline Populus deltoides Bartr. ex Marsh. & $3,641.1$ & 6.850 & 0.80 \\
\hline Salix interior Rowlee & $2,587.0$ & 5.367 & 1.00 \\
\hline Salix L. & 160.0 & 1.586 & .20 \\
\hline Unknown snag & $2,064.0$ & .758 & .60 \\
\hline Salix nigra Marsh. & 64.0 & .478 & .40 \\
\hline Platanus occidentalis $\mathrm{L}$. & 27.9 & .006 & .40 \\
\hline \multicolumn{4}{|c|}{ Box-elder Forest-CEGL005033 ( $\boldsymbol{n}=11)$} \\
\hline Acer negundo L. & 482.4 & 8.979 & 0.91 \\
\hline Morus L. & 87.7 & 6.129 & .73 \\
\hline Acer saccharinum $\mathrm{L}$. & 110.2 & 3.906 & .73 \\
\hline Ulmus $\mathrm{L}$. & 58.4 & .855 & .36 \\
\hline Robinia pseudoacacia $\mathrm{L}$. & 0.9 & .787 & .09 \\
\hline Populus deltoides Bartr. ex Marsh. & 11.2 & .453 & .45 \\
\hline Fraxinus L. & $1,067.3$ & .401 & .64 \\
\hline Celtis L. & 91.2 & .285 & .45 \\
\hline Carya Nutt. & 1.8 & .111 & .09 \\
\hline Cornus L. & 26.4 & .028 & .18 \\
\hline Toxicodendron radicans $(\mathrm{L}$.$) Kuntze$ & 7.3 & .024 & .09 \\
\hline Salix interior Rowlee & 75.6 & .006 & .09 \\
\hline Salix nigra Marsh. & 3.6 & .006 & .18 \\
\hline Salix caroliniana Michx. & 38.0 & .248 & .29 \\
\hline Platanus occidentalis L. & 49.3 & .215 & .20 \\
\hline Morus L. & 6.0 & .064 & 0.05 \\
\hline Acer saccharinum $\mathrm{L}$. & 33.0 & .052 & .07 \\
\hline Salix L. & 4.7 & .044 & .03 \\
\hline Vitis L. & 126.9 & .016 & .25 \\
\hline Celtis L. & 0.1 & .015 & .01 \\
\hline Campsis radicans (L.) Seem. ex Bureau & 115.5 & .014 & .28 \\
\hline Cornus L. & 4.7 & .006 & .05 \\
\hline Toxicodendron radicans (L.) Kuntze & 6.2 & .002 & .03 \\
\hline Fraxinus L. & 5.2 & .002 & .07 \\
\hline \multicolumn{4}{|c|}{ Woody old field $(n=4)$} \\
\hline Platanus occidentalis L. & 29.7 & 0.071 & 0.25 \\
\hline Fraxinus L. & 89.1 & .061 & .25 \\
\hline Celtis L. & 609.0 & .048 & .50 \\
\hline Populus deltoides Bartr. ex Marsh. & 14.9 & .029 & .25 \\
\hline Salix nigra Marsh. & 14.9 & .001 & .25 \\
\hline Ulmus L. & 14.9 & .001 & .25 \\
\hline
\end{tabular}


cottonwood (Populus deltoides), black willow (Salix nigra), mulberry (Morus spp.), and elm (Ulmus spp.). Most forests identified as the boxelder and silver maple types were mature, having established on fallow lands long before the floods of 1993 and 1995. Both types tended to include cottonwoods as an emergent canopy component.

Communities in which vegetative cover from woody stems in the shrub or tree layers exceeded approximately 20 percent but did not match any recognized NVCS community type were classified as Woody Old Fields. These comprised 3 percent (4 out of 132) of the forested plots. This community tended to have low woody stem density and low basal area and was dominated by ruderal species such as hackberry (Celtis spp.), ash (Fraxinus spp.), and elm (Ulmus spp.; table 3). Cottonwood (Populus deltoides) and willow (Salix spp.) were present but not dominant in this type. Tree density ranged from 20 to $410 \mathrm{stems} / \mathrm{ha}$ with a mean of $130.0 \mathrm{stems} / \mathrm{ha}$; basal area ranged from 0.002 to $0.051 \mathrm{~m}^{2} /$ ha with a mean of $0.035 \mathrm{~m}^{2} / \mathrm{ha}$. Woody old fields appear to be succeeding toward the Central Green Ash-Elm-Hackberry Forest (CEGL002014), a type with which it shares many dominant species.

Multivariate analysis using Non-metric Multidimensional Scaling (NMS) reveals four primary groups of community types (fig. 4 and fig. 5); 1) mature forests, 2) woody old fields, 3) cottonwood woodlands, and 4) immature cottonwood forests and willow thickets. The mature forest group includes Box-elder Floodplain Forests (CEGL005033), Silver MapleElm Forests (CEGL002586), and mature Midwestern Cottonwood-Black Willow Forests (CEGL002018). Analyses using Multiple Response Permutation Procedure (MRPP) indicates that these communities cannot be identified as unique groups; results change between analysis based on basal area and analysis based on density (table 4 and table 5). This reflects the fact that within the study area, these community types were usually encountered as mature forests within which cottonwoods share dominance with other species. Not coincidentally, they also tend to occur in the same locations - outside of protected levees in locations lacking agricultural production before 1993. The small sample size for the silver maple forest may have made it difficult to detect differences between it and the other types.

Cottonwood Floodplain Woodlands (CEGL002017) and Woody Old Fields are two community types found in close proximity to each other in the NMS outputs (fig. 4 and fig. 5), reflecting their shared characteristics of low overall basal area and density. Comparisons between these types using MRPP indicate significant differences based on density data $(T=-3.012$; table 5), but not based on basal area $(T=-1.242$; table 4). In the field, they are discernable from each other by differences in species assemblage and structure. Cottonwood woodlands are dominated by moderate to large diameter cottonwood (Populus deltoides) and willow (Salix spp.) stems. Woody Old Fields currently are dominated by uniformly short, small diameter stems of species that thrive in former agricultural flood plains, including ash (primarily Fraxinus pennsylvanica), hackberry (Celtis spp.), sycamore (Platanus occidentalis) and elm (Ulmus spp.). The structure of Woody Old Fields should change as woody stems mature.

The final group of communities includes immature Midwestern Cottonwood-Black Willow Forests (CEGL002018), Sandbar Willow Shrublands (CEGL008562), and Black Willow Riparian Forests (CEGL002103). Within the NMS analyses (fig. 4 and fig. 5), there is substantial overlap among the three types, though MRPP analysis based on density identifies significant differences between them (table 5). The sandbar willow shrubland has a distinct structure (high stem density and low canopy) and species composition (dominance by Salix interior) that justify retaining and mapping it as a distinct type. Similarly, MRPP analyses based on basal area and density indicate that the black willow forest type is statistically discernable from the cottonwood forest; however, the NVCS description for the black willow forest suggests that it is not extant in the study area and that small areas fitting the description for the type are a common component of the cottonwoodwillow forest. This is consistent with observations made in the field, where examples of the black willow forest tended to be small inclusions within a matrix cottonwood-willow forest. Given these facts, a decision was made to map locations initially classified as the Black Willow Riparian Forest (CEGL002103) as the Midwestern Cottonwood-Black Willow Forest (CEGL002018). Observations made during 2007 and 2009 suggest that flooding in low-lying cottonwood forests appear to be driving succession toward the black willow type. Given time, the Black Willow Riparian Forest (CEGL002103) type may become a more abundant and distinct type worthy of recognition within the refuge and throughout the Missouri River flood plain.

The species with the highest correlation to the data structure in the NMS outputs are cottonwood (Populus deltoides; basal area multiple $r^{2}=0.45$, density multiple $r^{2}=0.37$ ), snags (basal area multiple $r^{2}=0.36$, density multiple $r^{2}=0.40$ ), and sandbar willow (Salix interior; basal area multiple $r^{2}=0.22$, density multiple $r^{2}=0.33$ ). Other species with high correlation coefficients included mulberry (Morus spp.), ash (Fraxinus spp.), silver maple (Acer saccharinum) and boxelder (Acer negundo), which tended to have inverse relations with the above species. These results reflect the observable species abundance gradients (table 3 ) and suggest that the NMS analyses grouped plots based upon the same criteria identified through subjective analysis of the data and field observations.

\section{Herbaceous Communities}

The combined plot data from all sampling events support the occurrence of four recognizable herbaceous community types on bottomlands of the refuge. Four plots being managed via seeding of warm season grasses match the NVCS description for the Central Wet-Mesic Tallgrass Prairie (CEGL002024). This type is characterized by grasses such as big bluestem (Andropogon gerardii), little bluestem (Schizachyrium scoparium), Indiangrass (Sorghastrum nutans), and Eastern gamagrass (Tripsacum dactyloides). Midwest 


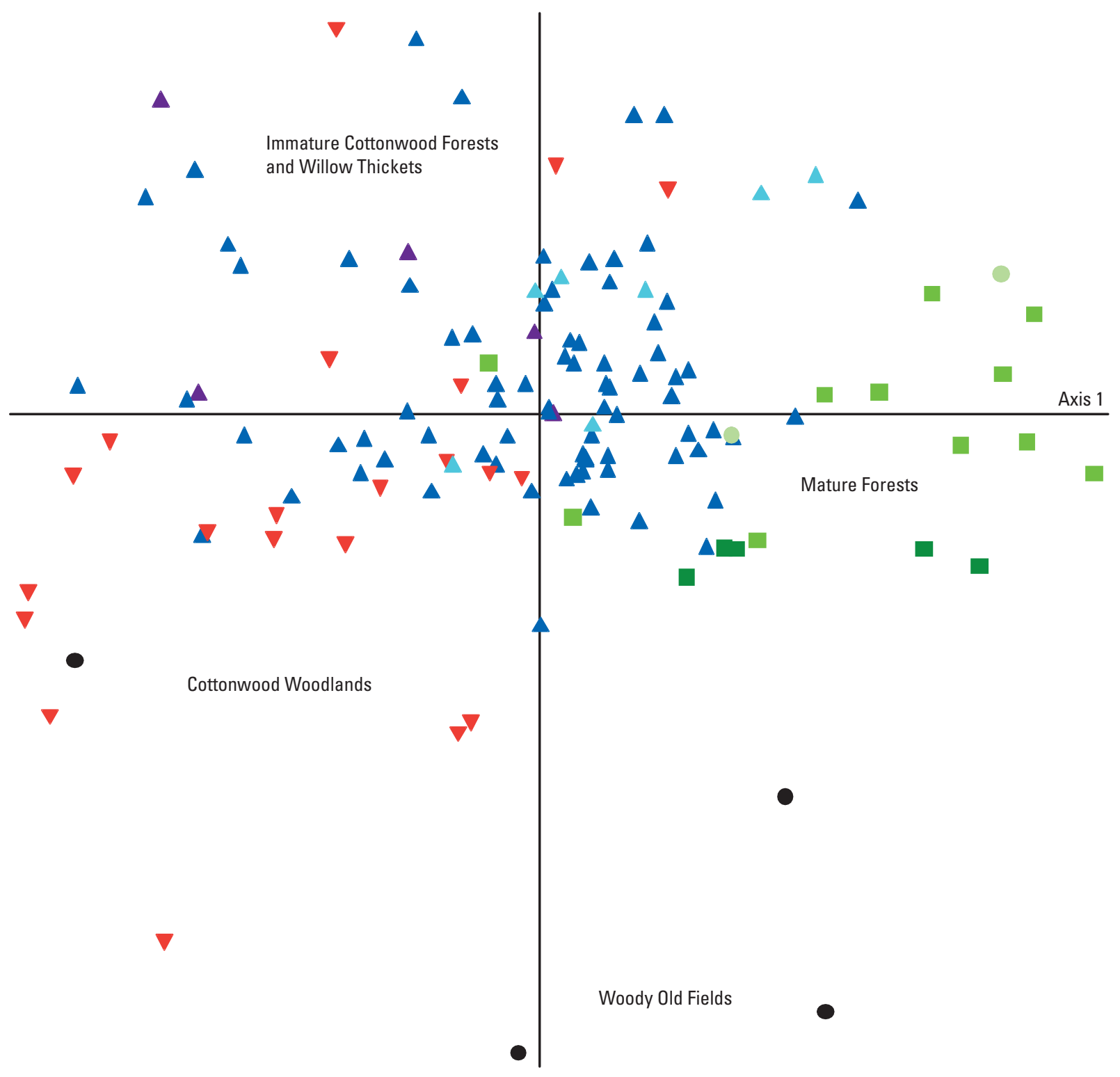

\section{EXPLANATION}

\section{Vegetation Association}

(National Vegetation Classification System code)

- Woody Old Field

$\checkmark$ Cottonwood Floodplain Woodland (CEGL002017)

- Silver Maple-Elm Forest (CEGL002586)

B Black Willow Riparian Forest (CEGL002103)

- Box-elder Floodplain Forest (CEGL005033)

$\triangle$ Sandbar Willow Shrubland (CEGL008562)

- Immature Midwestern Cottonwood-Black Willow Forest (CEGL002018)

Midwestern Cottonwood-Black Willow Forest (CEGL002018)

Figure 4. Non-metric Multidimensional Scaling output for woody communities based on woody stem basal area. 


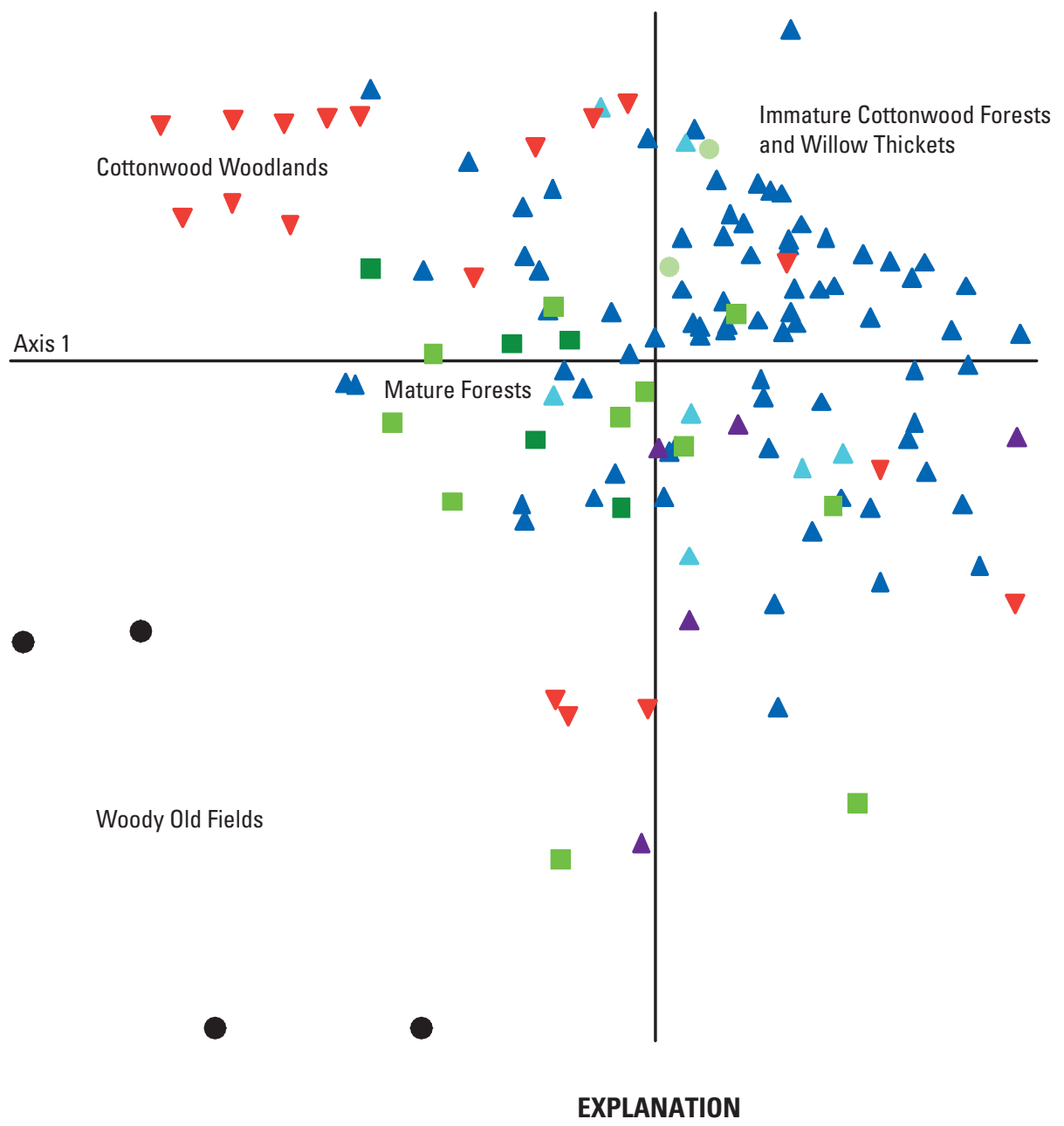

\footnotetext{
Vegetation Association

(National Vegetation Classification System code)

Woody Old Field

$\checkmark$ Cottonwood Floodplain Woodland (CEGL002017)

Silver Maple-Elm Forest (CEGL002586)

$\triangle$ Black Willow Riparian Forest (CEGL002103)

Box-elder Floodplain Forest (CEGL005033)

- Sandbar Willow Shrubland (CEGL008562)

- Immature Midwestern Cottonwood-Black Willow Forest (CEGL002018)

Midwestern Cottonwood-Black Willow Forest (CEGL002018)
}

Figure 5. Non-metric Multidimensional Scaling output for woody communities based on woody stem density. 


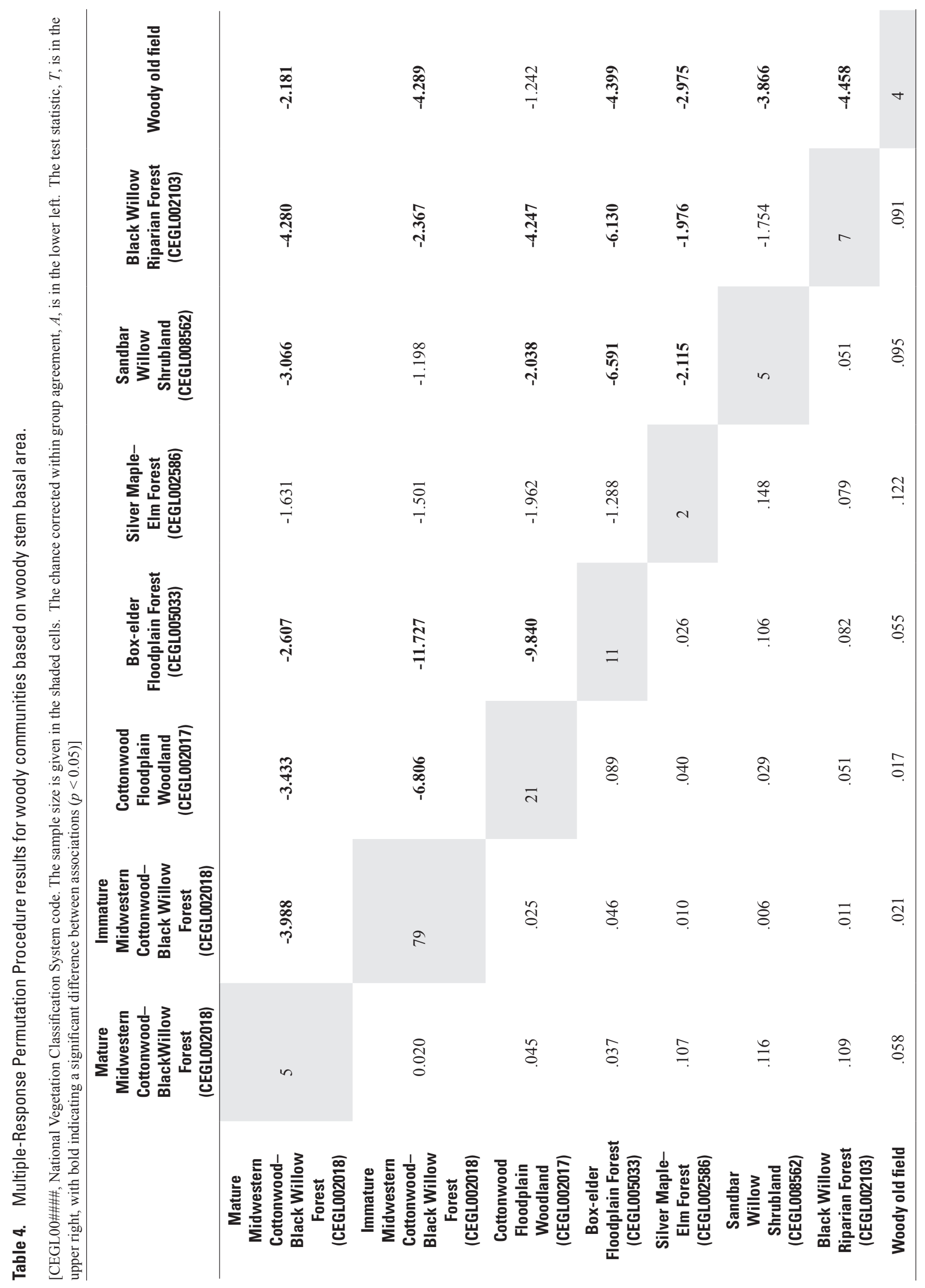




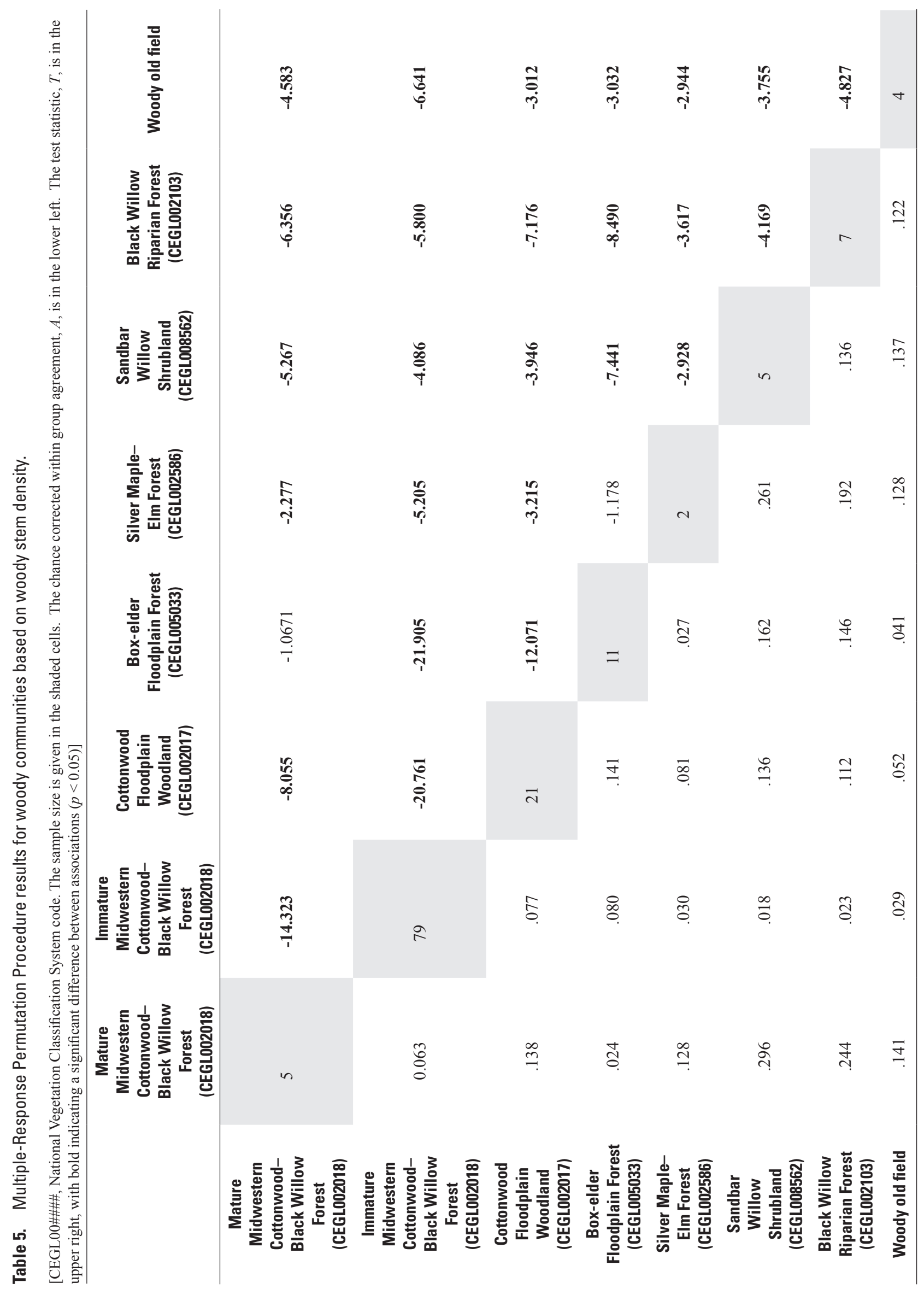


Ephemeral Pond (CEGL002430) communities are found at locations on the flood plain where water collects because of terrain and poorly-drained soils. They are dominated by smartweeds (Polygonum spp.) and sedges (Cyperus spp., and Carex spp.). Communities dominated by Johnson grass (Sorghum halepense) and ticktrefoil (Desmodium spp.) were classified as Johnson Grass communities, a type not recognized by the NVCS (NatureServe, 2009). This community is of interest because Johnson grass is a noxious weed for which the refuge has implemented a control program. Herbaceous Old Fields (another type not recognized in the NVCS) are dominated by herbaceous vines (Ipomoea spp., Calystegia spp., Cynanchum laeve and the noxious weed, Convolvulus arvensis), ragweed (Ambrosia spp.), and exotic grasses such as foxtail (Setaria viridis) and barnyard grass (Echinochloa crus-galli). Trumpet creeper (Campsis radicans) is also abundant. Numerous other herbaceous communities, including Riverine Sand Flats (CEGL002049) and various cultural types were encountered during map production, though no plot data were collected.

NMS analysis based on ground flora cover data indicates distinct clusters for the Central Wet-Mesic Tallgrass Prairie (CEGL002024) and the Johnson Grass communities (fig. 6). Both of these communities are characterized by a few dominant species, making their classification in the field relatively consistent. The prairie community also reflects the effect of a single management effort applied across a contiguous area to encourage that type. The broader expression of the Midwestern Ephemeral Pond (CEGL002430) and the Herbaceous Old Field types (fig. 6) is probably because of numerous factors. First, because plots represent communities from a broad range of times since the cessation of agricultural practices, numerous successional stages are represented. Second, sampling covered a broad spectrum of time following various flood events within each sampling season; sampling shortly after flood waters recede will detect a distinct set of species compared to sampling conducted with greater temporal separation from flood events. Finally, the Herbaceous Old Field type served as a catch-all for types not matching the other communities identified (preliminary attempts to identify subtypes within the old field class proved unreliable). The overlap between the two communities can be explained by the fact that most Polygonum wetlands are converting from herbaceous old fields and retain many of the species associated with the latter type. MRPP analysis $(T=-6.880, A=0.085, p<0.05)$ indicates that all of the herbaceous communities are distinct from one another, except when comparing Polygonum wetlands to Herbaceous Old Fields (table 6).

Moisture gradients appear to drive most of the differences between herbaceous community types. The output from the NMS analysis of herbaceous communities includes vectors representing the species most closely correlated (multiple $r^{2}$ greater than 0.3) to the data structure (fig. 6). Vectors begin at the origin, with the direction of the vector indicating the direction of increase, and the length of the vector indicating the relative correlation of each species. The separation of the Central Wet-Mesic Tallgrass Prairie (CEGL002024) along the vertical axis is driven, in large part, by a suite of species that can tolerate seasonally drier conditions, such as Croton spp., Diodia teres, Paspalum laeve, and Sorghastrum nutans as shown on figure 6 . The expected management gradient separating the Central Wet-Mesic Tallgrass Prairie (CEGL002024) from the other types was not identified, as Sorghastrum nutans is the only species with a high correlation that also was included in the seed mixture used to promote the prairie community. Johnson Grass and Herbaceous Old Field communities are separated along Axis 1 (fig. 6) by a shift from dominance by species that thrive in flood-prone areas, such as Lippia lanceolata and Xanthium spp., toward dominance by trumpet creeper (Campsis radicans), cover for which diminished substantially in response to flooding during the 2007 and 2008 growing seasons. Axis 2 is correlated with a shift from species that were more abundant in higher, drier flood-plain land forms (Aster pilosus, Desmodium paniculatum and Solidago altissima) to species that were more commonly found in lower, wetter flood-plain landforms during this study, such as Cynanchum laeve and Ipomoea spp. (vectors for these species are excluded for simplicity).

\section{Map Production}

The final map includes 482 polygons of 27 vegetation community types (some described communities were not included in the final map) and covers 3,174 hectares on five units of the refuge (table 6). By far, the most abundant mapped community is the Midwestern Cottonwood-Black Willow Forest (CEGL002018), with 106 polygons covering more than one-half of the mapped area. This community was dominant at all management units of the refuge, with a mean stand size of $17 \mathrm{ha}$. Also abundant was the Cottonwood Floodplain Woodland (CEGL002017), which covered 214 ha in 26 polygons, primarily at Overton Bottoms, Lisbon Bottom, and Saint Aubert Island. Other abundant bottomland communities included the Sandbar Willow Shrubland (CEGL008562; 147 ha), the Riverine Sand Flats (CEGL002049; 107 ha), the Midwest Ephemeral Pond (CEGL002430; 94 ha), and the Silver Maple-Elm Forest (CEGL002586; 78 ha).

Most of the ruderal communities were mapped at the Overton Bottoms unit (fig. 7). These were dominated by Herbaceous Old Fields (92 ha), a type with a wide expression that seems to be limited to higher, drier bottomland landforms. Also abundant are woody old fields, covering approximately 84 ha in both upland and bottomland expressions. The least abundant ruderal community was the Johnson Grass type, which was mapped on 31 ha.

Less abundant were communities of particular interest to the refuge (table 7). The Central Wet-Mesic Tallgrass Prairie (CEGL002024) occurred on only four patches covering 37 ha. These were located in areas that have been managed for the type using drill and broadcast seeding. Also uncommon was the Ash-Oak-Sycamore Mesic Bottomland Forest 


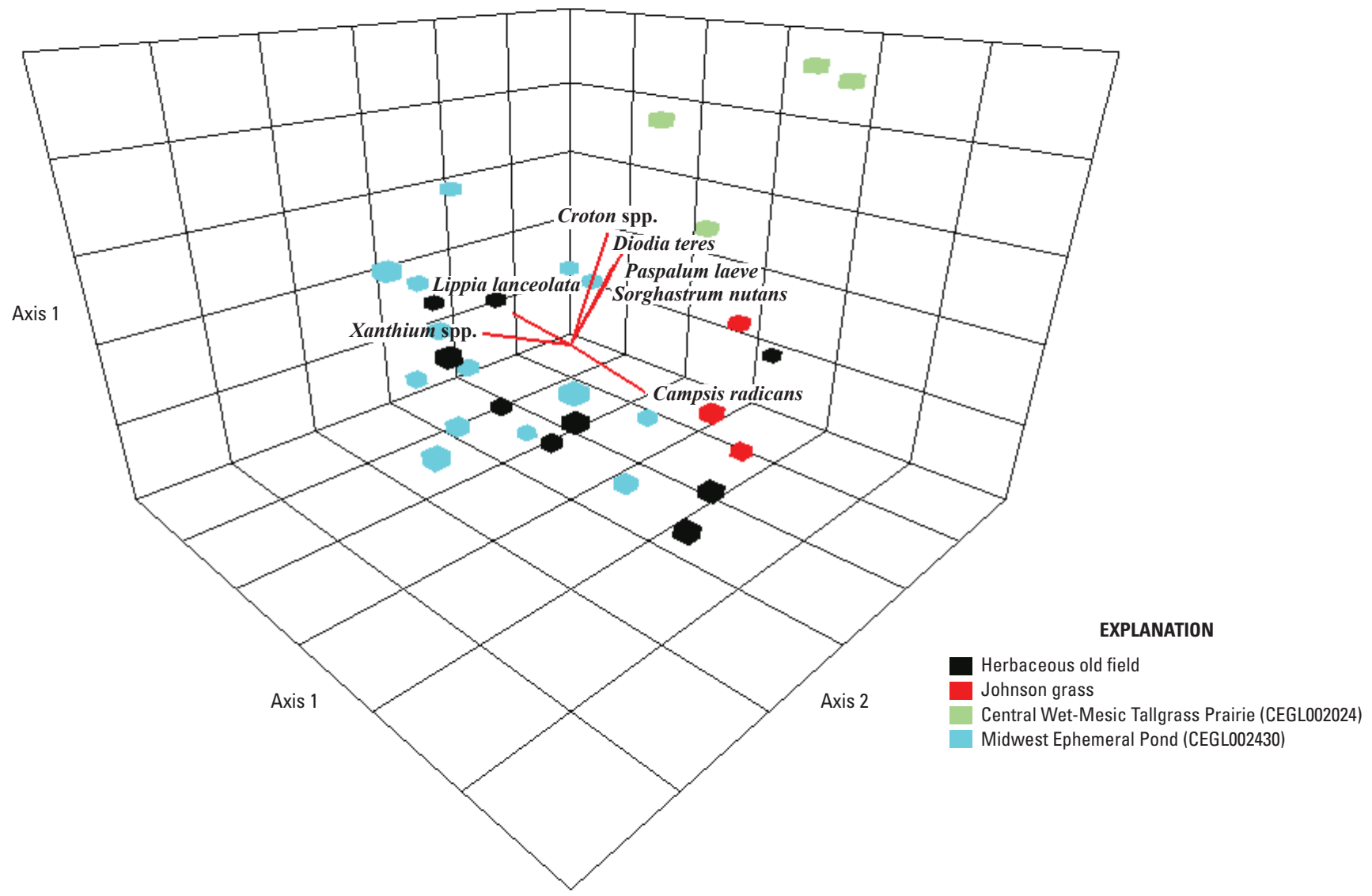

Figure 6. Non-metric Multidimensional Scaling output for herbaceous communities with vectors indicating direction of increase for those species most correlated with the data structure.

Table 6. Results of Multiple Response Permutation Procedure analysis of herbaceous communities.

[CEGL00\#\#\#, National Vegetation Classification System code. The sample size is given in the shaded cells. The chance corrected within group agreement, $A$, is in the lower left. The test statistic, $T$, is in the upper right, with bold indicating a significant difference between associations $(p<0.05)$.]

\begin{tabular}{ccccc}
\hline & Herbaceous old field & Johnson grass & $\begin{array}{c}\text { Midwest Ephemeral Pond } \\
\text { (CEGL002430) }\end{array}$ & $\begin{array}{c}\text { Central Wet-Mesic } \\
\text { Tallgrass Prairie } \\
\text { (CEGL002024) }\end{array}$ \\
\hline $\begin{array}{c}\text { Herbaceous old field } \\
\text { Johnson grass }\end{array}$ & 11 & $\mathbf{- 3 . 1 9 2}$ & 0.088 & $\mathbf{- 5 . 7 6 7}$ \\
$\begin{array}{c}\text { Midwest Ephemeral Pond } \\
\text { (CEGL002430) }\end{array}$ & .066 & 3 & $\mathbf{- 4 . 5 4 1}$ & $\mathbf{- 3 . 0 0 2}$ \\
$\begin{array}{c}\text { Central Wet-Mesic } \\
\text { Tallgrass Prairie } \\
\text { (CEGL002024) }\end{array}$ & -.001 & .076 & 14 & $\mathbf{- 5 . 9 3 4}$ \\
\hline
\end{tabular}




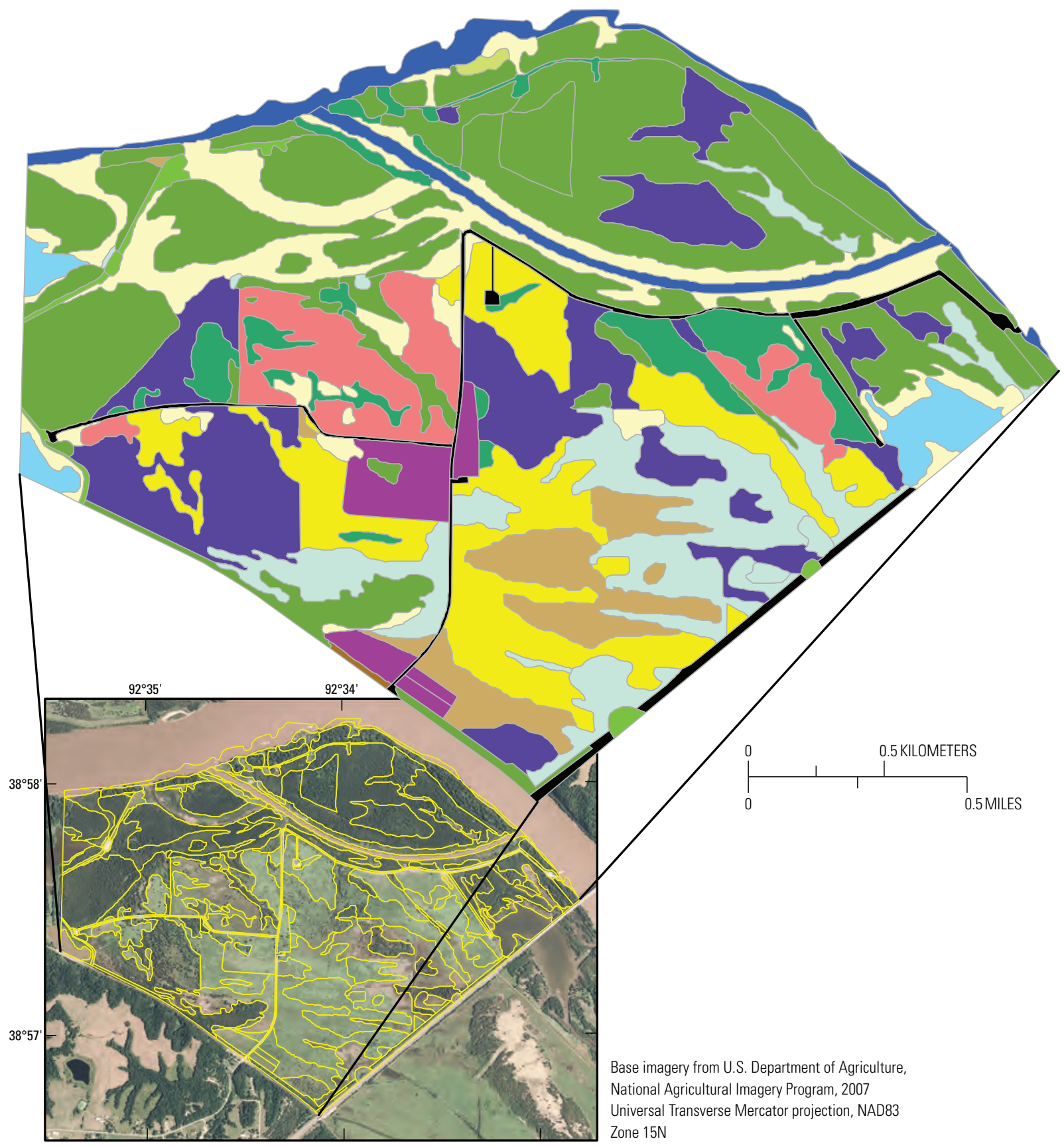

EXPLANATION
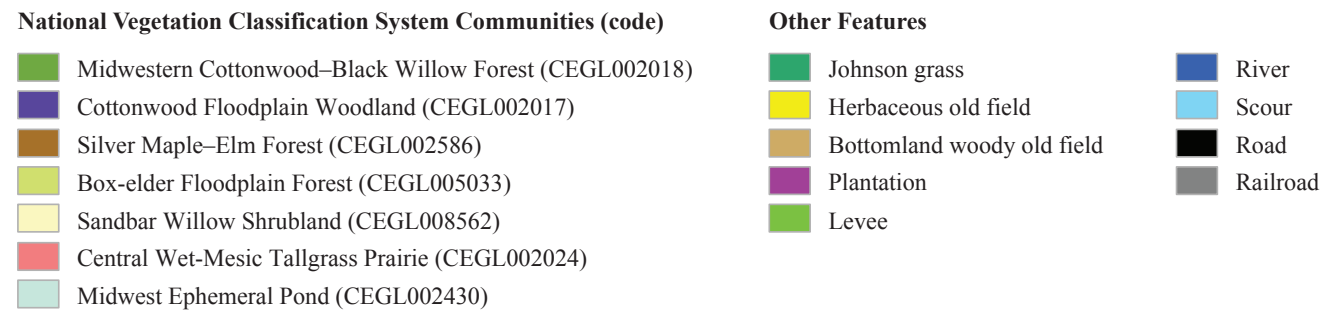

Figure 7. Vegetation for portion of floodplain at Overton Bottoms unit at Big Muddy National Fish and Wildlife Refuge, Missouri. 
Table 7. Polygon count and area for mapped communities at Big Muddy National Fish and Wildlife Refuge.

[NA, not applicable]

\begin{tabular}{|c|c|c|c|c|c|}
\hline $\begin{array}{l}\text { National Vegetation Classification System (NVCS) } \\
\text { common name or project community name }\end{array}$ & $\begin{array}{l}\text { NVCS } \\
\text { code }\end{array}$ & $\begin{array}{l}\text { Number } \\
\text { of plots }\end{array}$ & $\begin{array}{l}\text { Number } \\
\text { of map } \\
\text { points }\end{array}$ & $\begin{array}{c}\text { Number of } \\
\text { mapped } \\
\text { polygons } \\
\text { (mapped as) }\end{array}$ & $\begin{array}{c}\text { Total } \\
\text { mapped } \\
\text { area } \\
\text { (hectares) }\end{array}$ \\
\hline \multicolumn{6}{|c|}{ Forest } \\
\hline \multicolumn{6}{|c|}{ Upland } \\
\hline White Oak-Red Oak-Sugar Maple Mesic Forest & CEGL002058 & 0 & 4 & 8 & 14.73 \\
\hline White Oak/Dogwood Dry-Mesic Forest & CEGL002066 & 0 & 4 & 5 & 21.48 \\
\hline White Oak-Mixed Oak Dry-Mesic Alkaline Forest & CEGL002070 & 0 & 1 & $\begin{array}{c}0 \\
(\text { CEGL002066) }\end{array}$ & 0 \\
\hline Midwest Post Oak-Blackjack Oak Forest & CEGL002075 & 0 & 2 & $\begin{array}{c}0 \\
(\text { CEGL004803) }\end{array}$ & 0 \\
\hline Black Oak-White Oak-Hickory Forest & CEGL002076 & 0 & 7 & 6 & 26.78 \\
\hline Ozark Red-cedar-Hardwood Forest & CEGL004803 & 0 & 9 & 11 & 59.75 \\
\hline \multicolumn{6}{|c|}{ Bottomlands } \\
\hline Midwestern Cottonwood-Black Willow Forest & CEGL002018 & 84 & 132 & 106 & 1892.02 \\
\hline Black Willow Riparian Forest & CEGL002103 & 7 & 6 & $\begin{array}{c}0 \\
(\text { CEGL002018) }\end{array}$ & 0 \\
\hline Silver Maple-Elm Forest & CEGL002586 & 2 & 17 & 15 & 77.81 \\
\hline Central Green Ash-Elm-Hackberry Forest & CEGL002014 & 0 & 1 & $\begin{array}{c}0 \\
(\mathrm{CEGL002586)}\end{array}$ & 0 \\
\hline Ash-Oak-Sycamore Mesic Bottomland Forest & CEGL002410 & 0 & 2 & 2 & 5.27 \\
\hline Box-elder Floodplain Forest & CEGL005033 & 11 & 18 & 22 & 14.55 \\
\hline \multicolumn{6}{|c|}{ Woodland } \\
\hline Cottonwood Floodplain Woodland & CEGL002017 & 21 & 41 & 26 & 213.75 \\
\hline \multicolumn{6}{|c|}{ Shrubland } \\
\hline Sandbar Willow Shrubland & CEGL008562 & 5 & 57 & 66 & 147.11 \\
\hline \multicolumn{6}{|c|}{ Herbaceous } \\
\hline Central Wet-Mesic Tallgrass Prairie & CEGL002024 & 4 & 8 & 4 & 36.61 \\
\hline Midwest Ephemeral Pond & CEGL002430 & 14 & 34 & 42 & 94.10 \\
\hline Riverine Sand Flats & CEGL002049 & 0 & 16 & 17 & 107.09 \\
\hline \multicolumn{6}{|c|}{ Ruderal } \\
\hline Herbaceous old field & NA & 11 & 19 & 22 & 92.57 \\
\hline Fescue field & NA & 0 & 5 & 5 & 14.63 \\
\hline Bottomland woody old field & NA & 4 & 24 & 9 & 34.74 \\
\hline Upland woody old field & NA & 0 & 5 & 10 & 50.02 \\
\hline Johnson grass & NA & 3 & 12 & 18 & 31.09 \\
\hline \multicolumn{6}{|c|}{ Other features } \\
\hline Levee & NA & 0 & 8 & 13 & 12.71 \\
\hline Plantation & NA & 0 & 5 & 5 & 17.34 \\
\hline Pond & NA & 0 & 11 & 12 & 7.59 \\
\hline Railroad & NA & 0 & 5 & 3 & 7.68 \\
\hline River & NA & 0 & 17 & 33 & 84.48 \\
\hline Road & NA & 0 & 7 & 17 & 23.94 \\
\hline Row crop & NA & 0 & 2 & 2 & 20.97 \\
\hline Scour & NA & 0 & 2 & 3 & 13.41 \\
\hline Utility right-of-way & NA & 0 & 0 & 1 & 2.72 \\
\hline
\end{tabular}


(CEGL002410; 5 ha), which was limited to a few narrow ravines in the upland parcel at Overton Bottoms.

The uplands were dominated by white oak forests (table 7; fig. 8). The White Oak-Red Oak-Sugar Maple Mesic Forest (CEGL002058) was mapped on 15 ha, primarily low, mesic, north-facing slopes. Often, this community was associated with limestone bluffs, where sugar maple became more dominant and the canopy tended to be patchy. On dry-mesic slope positions, there is a transition to the White Oak/Dogwood Dry-Mesic Forest (CEGL002066; 21 ha). This can be replaced by an alkaline version (CEGL002070) where carbonate bedrock is at or near the surface, but the few examples observed were too small to warrant inclusion in the final map. However, species that thrive on base-saturated soils, especially Chinkapin oak (Quercus muehlenbergii) and white ash (Fraxinus americana), were abundant throughout the uplands, suggesting a strong potential for the alkaline type. Even drier landscape positions support the Black Oak-White OakHickory Forest (CEGL002076; $27 \mathrm{ha}$ ) and then the Ozark Red-cedar-Hardwood Forest (CEGL004803; 60 ha). The latter type tends to be limited to upper south-facing slopes. Ruderal community types in the uplands include Fescue Field and Upland Woody Old Fields, two types whose differences appear to arise from differences in the time since the cessation of agricultural activity, especially hay production

\section{Management Implications}

Record flooding in 1993 and 1995 across broad areas on the refuge allowed establishment of abundant Midwestern Cottonwood-Black Willow Forests (CEGL002018). Stands of this type appear to have entered a stem-exclusion stage consistent with wholesale stand regeneration. Suppressed stems are being shaded out, creating canopy gaps that will last until the crowns of surviving trees expand to fill the vacated space. At the same time, flood dynamics are creating a more heterogeneous structure by increasing mortality in low lying areas where flooding appears to be more intense (deeper and more prolonged with greater flow rates). This action appears to create greater mortality in cottonwoods than in willows, which might drive succession towards the Black Willow Riparian Forest (CEGL002103), a type that was tentatively identified but not mapped on the refuge. Study data suggest that the global description for the Black Willow Riparian Forest should indicate this type as extant in Missouri and the study area. The refuge will be an excellent location to test whether Black Willow Riparian Forest can sustain itself as successional and disturbance processes continue.

The Silver Maple-Elm Forest (CEGL002586) is currently limited to riverfront locations outside of protected levees and adjacent to back channels, sloughs and scours. It is reasonable to expect this type to expand, but that expansion will be limited by the availability of suitable sites. From a habitat perspective, it does not appear to be particularly different from mature cottonwood forests, with which it shares many species. Management directed toward increasing the abundance of the silver maple forest may prove unreliable and inefficient given the risk of high-intensity floods.

Box-elder Floodplain Forest (CEGL005033) appears to be limited to stable protected landforms that had been removed from agricultural production before the floods in 1993 and 1995: it is dominated by mature trees, primarily boxelder with an emergent canopy of cottonwoods. The NVCS description of this type suggests that it represents a ruderal community indicative of past agricultural activity (NatureServe, 2009). Its presence may be hindering the establishment of communities that would otherwise be found in the flood plains (for example, where it is found, there are few cottonwood seedlings or saplings). As these stands mature, they may yield to mixed bottomland forests with a greater abundance of hardwood species, particularly ash (Fraxinus spp.), oak (Quercus spp.) and pecan (Carya illinoinensis), seedlings of which are occasionally found beneath the canopy of the boxelder forests.

The refuge is particularly interested in increasing the abundance of mixed hardwood bottomland communities, but these are rarely encountered on the flood plains of the refuge. Only two examples of a mixed hardwood type were found which matched the description for the Ash-Oak-Sycamore Mesic Bottomland Forest (CEGL002410) and these were found in draws of the upland parcel at Overton Bottoms. These represent a forest type intermediate between oak-dominated bottomland forests and the Central Green Ash-Elm-Hackberry Forest (CEGL002014). Only one example of the latter type was identified during sampling, of a size too small to map; however, bottomland old fields with high woody stem densities appear to be succeeding toward the CEGL002014 type. Management practices encouraging oak production in woody old fields may be an efficient means of shifting the successional trajectory of old fields toward the Ash-Oak-Sycamore Mesic Bottomland Forest (CEGL002410) to meet the management objective of increasing the abundance of mixed-hardwood forests.

Cottonwood Floodplain Woodlands (CEGL002017) have become established on higher, somewhat drier flood-plain landforms. They are not subject to the same flood intensity that can be found in lower areas, and appear to be stable. As natural thinning progresses in Midwestern Cottonwood-Black Willow Floodplain Forests (CEGL002018), they may succeed toward the woodland type. The open canopy of the woodland type appears to make it susceptible to invasion by Johnson grass.

Sandbar Willow Shrublands (CEGL008562) are abundant adjacent to channels, chutes and sloughs, where dynamic flooding creates a mosaic of deposition and scour features. They can also be found on the flood plain in low lying areas with high flood intensity. Though the type is abundant and in little danger of extirpation from the refuge, changes in its abundance could be affected by alterations that increase the heterogeneity of the river channel morphology. Management for shallow water habitat and the creation of chutes and 


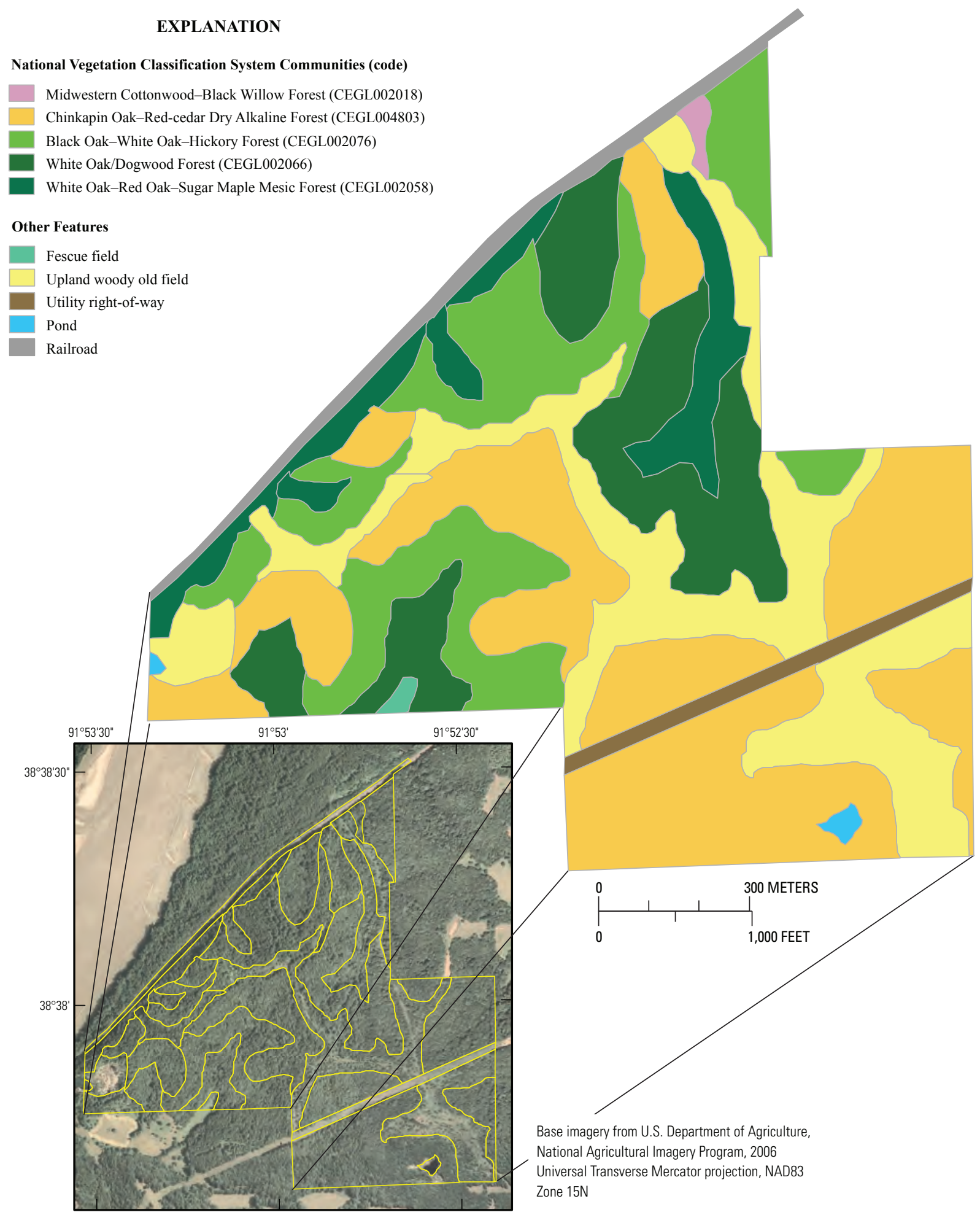

Figure 8. Vegetation for upland section of Saint Aubert Island unit at Big Muddy National Fish and Wildlife Refuge, Missouri. 
other novel avenues for stream flow are possible management actions that would change the abundance of this type.

Expressions of the Central Wet-Mesic Tallgrass Prairie (CEGL2024)) are determined predominantly by specific management actions to increase that type on the refuge, most notably, seeding warm-season grasses. If the refuge is able to control or reverse the spread of the nonnative invasive Johnson grass (Sorghum halepense), the prairie type should become more abundant. Prescribed fire is a common tool used to stimulate prairie restoration, but its use on the refuge may increase the abundance of Johnson grass, which is found at many locations throughout the refuge and increases in abundance in response to fire. Given the small area classified as the prairie community type, it is difficult to assess landform-based differences in the success or failure of management actions intended to increase the prairie community.

Flooding in 2007, 2008, and 2009 has dramatically increased the abundance of the Midwest Ephemeral Pond community (CEGL002430). Many locations that would have been classified as Herbaceous Old Field based on 2002-04 data had converted to this wetland type by the final sampling for map production in 2009. This is even true for areas in which 2007 data suggested an old field type. Not surprisingly, this type can be found in low, water-retaining areas on the flood plain. The examples with the deepest and most prolonged flooding appear to be succeeding toward the Northern Buttonbush Swamp (CEGL002190) or the similar Southern Buttonbush Shrubland (CEGL002191). Buttonbush (Cephalanthus occidentalis) and Hibiscus spp., are becoming established, along with a variety of sedges. Efforts to increase the length of time water occupies these sites may further this succession.

Riverine Sand Flats (CEGL002049) were limited to point bars and high and low mud banks along the river channel and secondary chutes. They occasionally occur on high flats where flooding has removed woody vegetation and deposited sand or mud. In terms of species composition and flood dynamics, this type is little different than the Riverine Mud Flats (CEGL002314), a type excluded because "sand" better described the dominant substrate in the study area. Also, the sand flats description is consistent with Nelson's (2005) sandbar community for Missouri. The abundance of this community will most likely be affected by changes to the fluvial dynamics of the river itself. The species composition of this type is extremely variable.

It is difficult to predict the successional trajectory of ruderal communities. Recent prolonged flooding has lead to dramatic changes in the most abundant ruderal community type, bottomland herbaceous old fields. An increase in abundance of hydrophilic species, especially Polygonum spp., has directed succession in low lying areas toward the Midwest Ephemeral Pond (CEGL002430). For example, some communities that were identified as Herbaceous Old Fields dominated by drought tolerant grasses during sampling in 2007 were reclassified as the wetland type based on evidence collected during 2009 sampling. This change can be attributed to the flooding that occurred in the intervening years. At the same time, flooding has induced mortality among many woody species, especially trumpet creeper (Campsis radicans), shifting communities from the woody old field to the herbaceous old field or, in some cases, directly to the wetland type. Periods of prolonged drought might reverse these trends. Meanwhile, woody stems such as Celtis laevigata, Platanus occidentalis and Fraxinus pennsylvanica are colonizing drier old fields and pushing succession toward the Central Green Ash-Elm Hackberry Forest (CEGL002014). In some areas, Johnson grass is creating a static herbaceous community within which desirable native species struggle to establish.

Upland community distribution can most readily be understood within the context of moisture gradients. Progression from low, north-facing slopes to drier summits is accompanied by a progression from red oak (Quercus rubra) and white oak $(Q . a l b a)$ forests with sugar maple (Acer saccharum) through white oak dominated forests to mixed oak-hickory (Carya spp.) forests. Dry, upper south-facing slopes support open forests; however, the NVCS description for Ozark Red-cedar-Hardwood Forest (CEGL004803) is likely correct in its assertion that the type represents a fire-suppressed expression of an oak-dominated woodland (NatureServe, 2009). Fire suppression, along with the effects of past grazing, likely increased overall stem density and the abundance of eastern redcedar (Juniperus virginiana). Some sampling points within polygons classified as the CEGL004803 type originally had been identified as the Midwest Post Oak-Blackjack Oak Forest (CEGL002075), which is considered a fire-suppressed expression of an oak woodland without eastern redcedar. With management to remove eastern redcedar and decrease overall stem density (prescribed burning, for example), areas currently mapped as the Ozark Red-cedar-Hardwood Forest (CEGL004803) should start to resemble an OzarkOuachita Post Oak-Blackjack Oak / Little Bluestem Woodland (CEGL002149), which may have been more abundant historically.

A woody old field type can be found in the uplands, usually on summits and shoulders suitable for grazing. In the uplands, the dominant species in old fields are honey locust (Gleditsia triacanthos) and eastern redcedar (Juniperus virginiana). The presence of these long-lived species may hinder succession toward more desirable, oak-dominated forests and woodlands by suppressing establishment and survival of species indicative of those types. Fescue fields in the uplands only recently have been removed from grazing or hay production management. These will likely succeed toward the woody old field type. Both communities are susceptible to invasion by the nonnative invasive, Lespedeza cuneata, which can be found in abundance in upland locations at Saint Aubert Island. 


\section{References Cited}

Bailey, R.G., Avers, P.E., King, T., McNab, W.H., eds, 1994, Ecoregions and subregions of the United States (map). Washington, DC: U.S. Geological Survey, 1:7,500,000. Colored. Accompanied by a supplementary table of map unit descriptions compiled and edited by McNab, W.H. and Bailey, R.G. Prepared for the USDA Forest Service.

Bezzerides, N., Young N., Papon S., and Gallagher, M., 2003, Flood plain forests at bird point-count locations on the Big Muddy and Swan Lake National Fish and Wildlife Refuges: University of Missouri, School of Natural Resources, Department of Fisheries and Wildlife, and U.S. Fish and Wildlife Service, Columbia, Missouri, 18 p.

Cleland, D.T., Avers, P.E., McNab, W.H., Jensen, M.E., Bailey, R.G., King, T., and Russell, W.E., 1997, National hierarchical framework of ecological units, in Ecosystem Management: Applications for sustainable forest and wildlife resources, Boyce, M.S., and Haney, A., eds., Yale University Press, New Haven \& London, p. 181-200.

Faber-Langendoen, D., ed., 2001, Plant communities of the Midwest: Classification in an ecological context: Association for Biodiversity Information, Arlington, Virginia, 61 p., plus appendix.

Frayer, W. E., and Furnival, G. M., 1999, Forest survey sampling designs: A history: Journal of Forestry, v. 97, no. 12, p. $4-10$.

Funk, J.L., and Robinson, J.W., 1974, Changes in the channel of the lower Missouri River and effects on fish and wildlife: Aquatic Series No. 11, Missouri Department of Conservation, Jefferson City, Missouri, 52 p.

Galat, D.L., Fredrickson, L.H., Humburg, D.D., Bataille, K.L., Bodie,J.R., Dohrenwend, J., Gelwicks, G.T., Havel, J.E., Helmers, D.L., Hooker, J.B., Jones, J.R., Knowlton, M.F., Kubisiak, J., Mazourek, J., McColpin, A.C., Renken, R.B., Semlitsch, R.D., 1998, Flooding to restore connectivity of regulated, large-river wetlands: Bioscience, v. 48, no. 9, p. 721-733.

Grossman, D.H., Faber-Langendoen, D., Weakley, A.S., Anderson, M., Bourgeron, P., Crawford, R., Goodin, K., Landaal, S., Metzler, K., Patterson, K.D., Pyne, M., Reid, M., and Sneddon, L., 1998, International classification of ecological communities: terrestrial vegetation of the United States, Volume I; The National Vegetation Classification System: development, status, and applications: The Nature Conservancy, Arlington, Virginia, 126 p., 1 pls.

Gurnell, A., 1997, The hydrological and geomorphological significance of forested flood plains: Global Ecology and Biogeography Letters, v. 6, no. 3-4, p. 219-29.
Harlan, J.D., 2002, Lewis and Clark across Missouri: Curators of the University of Missouri, Department of Geography, Stewart Hall, Columbia, Missouri. ftp://msdis.missouri.edu/ pub/lewis_clark/histlc.e00.gz.

Jacobson, R.B., 2006, Introduction-science to support adaptive habitat management, Overton Bottoms North Unit, Big Muddy National Fish and Wildlife Refuge, Missouri: Chapter 1 of Jacobson, R.B., ed., Science to support adaptive habitat management-Overton Bottoms North Unit, Big Muddy National Fish and Wildlife Refuge, Missouri: U.S. Geological Survey, Science Investigations Report 20065086, p. 1-16.

Keys, Jr., J., Carpenter, C., Hooks, S.; Koenig, F., MC W.H., Russell, W., and Smith, M.L., 1995, Ecological units of the Eastern United States: first approximation: USDA Forest Service, Atlanta, GA.

Maybury, Kathleen P., ed., 1999, Seeing the Forest and the Trees: Ecological Classification for Conservation: The Nature Conservancy, Arlington, Virginia.

McCarty, K., Meinert, D., and DuCharme, C., 2004, Edward "Ted" and Pat Jones Confluence Point State Park: Revegetation and restoration plan: Missouri Department of Natural Resources, Jefferson City, Missouri, 43 p.

McCune, B., and Grace, J.B., 2002, Analysis of Ecological Communities: MjM Software Design, Gleneden Beach, Oregon, $300 \mathrm{p}$.

McCune, B., and Mefford, M.J., 1999, Multivariate analysis of ecological data-Versions 4: MJM Software Design, Gleneden Beach, Oregon, 237 p.

McCune, B., and Mefford, M.J., 2006, Multivariate analysis of ecological data-Versions 5: MJM Software Design, Gleneden Beach, Oregon, 234 p.

Missouri Spatial Data Information Service (MSDIS), 2006, www.msdis.missouri.edu, accessed May, 2006.

National Institute of Invasive Species Science (NIISS), 2007, Website of USGS Fort Collins Science Center, Fort Collins, Colorado, (www.niiss.org).

NatureServe, 2009, NatureServe Explorer: An online encyclopedia of life [web application], Version 7.1: NatureServe, Arlington, Virginia, (www.natureserve.org/explorer), accessed 28 December, 2009, www.natureserve.org/ explorer.

Nelson, P.W., 2005, The Terrestrial Natural Communities of Missouri: The Missouri Natural Areas Committee, The Missouri Department of Natural Resources, Jefferson City, Missouri, $550 \mathrm{p}$. 
Nigh, T.A., and Schroeder, W.A., 2002, Atlas of Missouri Ecoregions: Missouri Department of Conservation, Jefferson City, Missouri, 212 p.

Oliver, C.D., and Larson, B.C., 1990, Forest stand dynamics: McGraw-Hill, Inc., New York, NY., 467 p.

The Nature Conservancy, 1994, Standardized National Vegetation Classification System; Report to U.S. Dept. of Interior: The Nature Conservancy, Arlington, Virginia and Environmental Systems Research Institute, Redlands, California, 94 p., plus appendices, biology.usgs.gov/npsveg/ classificationrpt.pdf.

Steyermark, J., 1963, Flora of Missouri: The Iowa State University Press, Ames, Iowa. 1,725 p.

Stohlgren, T. J., Barnett, D.T., and Simonson, S.E., 2008, Beyond North American Weed Management Association standards: North American Weed Management Association, accessed October, 2008, Also available at www.niiss.org.

U.S. Department of Agriculture, Natural Resource Conservation Service, 2009, The PLANTS Database: National Plant Data Center, Baton Rouge, LA, Also available at http:// plants.usda.gov, 24 June 2010.

U.S. Fish and Wildlife Service (USFWS), 1999, Big Muddy National Fish and Wildlife Refuge Final Environmental Impact Statement: Department of the Interior, U.S. Fish and Wildlife Service, Also available at www.fws.gov/midwest/ planning/bigmuddy/index.html.

Weaver, J.E., 1960, Flood plain vegetation of the Central Missouri Valley and contacts of woodland and prairie: Ecological Monographs, v. 30, no. 1, p 37-64.

Yatskievych, G., 1999, Steyermark's Flora of Missouri, Volume 1: Missouri Department of Conservation, Jefferson City, Missouri, 991 p.

Yatskievych, G., 2006, Steyermark's Flora of Missouri, Volume 2: Missouri Botanical Garden Press, Saint Louis, Missouri, 1,181 p.

Young, N., 2004, Vegetation data collection standardized operating procedures for collection of vegetation measurements for the bottomland hardwood forest and early successional community research project; Internal Report: Big Muddy National Fish and Wildlife Refuge, Columbia, Missouri, $5 \mathrm{p}$. 



\section{Appendix 1}

The Microsoft Office Word document Appendix_1.docx compiles global descriptions of National Vegetation Classification System vegetation associations maintained by NatureServe (2009) with notes on local expressions of communities encountered during this study. 
Publishing support provided by:

Rolla Publishing Service Center

For more information concerning this publication, contact:

Director, USGS Columbia Environmental Research Center 4200 New Haven Road

Columbia, MO 65201

(573) 875-5399

Or visit the Columbia Environmental Research Center Web site at:

http://www.cerc.usgs.gov/ 



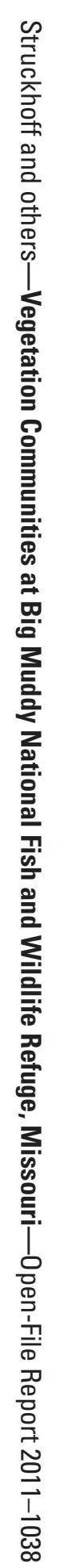

